\title{
Teaching Transnational Buddhist Meditation with Vipassanā (Neiguan 內觀) and Mindfulness (Zhengnian 正念) for Healing Depression in Contemporary China
}

\author{
Ngar-sze Lau
}

Citation: Lau, Ngar-sze. 2021. Teaching Transnational Buddhist Meditation with Vipassanā (Neiguan 內觀) and Mindfulness (Zhengnian 正 念) for Healing Depression in Contemporary China. Religions 12: 212. https://doi.org/10.3390/ rel12030212

Academic Editor: Brooke Schedneck

Received: 10 February 2021

Accepted: 17 March 2021

Published: 20 March 2021

Publisher's Note: MDPI stays neutral with regard to jurisdictional claims in published maps and institutional affiliations.

Copyright: (C) 2021 by the author. Licensee MDPI, Basel, Switzerland. This article is an open access article distributed under the terms and conditions of the Creative Commons Attribution (CC BY) license (https:// creativecommons.org/licenses/by/ $4.0 /)$.
Department of Special Education and Counselling, The Education University of Hong Kong, Hong Kong SAR, China; enslau@eduhk.hk

\begin{abstract}
This paper examines how the teaching of embodied practices of transnational Buddhist meditation has been designated for healing depression explicitly in contemporary Chinese Buddhist communities with the influences of Buddhist modernism in Southeast Asia and globalization. Despite the revival of traditional Chan school meditation practices since the Open Policy, various transnational lay meditation practices, such as vipassan $\bar{a}$ and mindfulness, have been popularized in monastic and lay communities as a trendy way to heal physical and mental suffering in mainland China. Drawing from a recent ethnographic study of a meditation retreat held at a Chinese Buddhist monastery in South China, this paper examines how Buddhist monastics have promoted a hybrid mode of embodied Buddhist meditation practices, mindfulness and psychoanalytic exercises for healing depression in lay people. With analysis of the teaching and approach of the retreat guided by welleducated Chinese meditation monastics, I argue that some young generation Buddhist communities have contributed to giving active responses towards the recent yearning for individualized bodily practices and the social trend of the "subjective turn" and self-reflexivity in contemporary Chinese society. The hybrid inclusion of mindfulness exercises from secular programs and psychoanalytic exercises into a vipassana meditation retreat may reflect an attempt to re-contextualize meditation in Chinese Buddhism.
\end{abstract}

Keywords: transnational meditation; vipassanā; mindfulness; mind; body; healing; depression; Han Chinese

\section{Introduction}

On the second evening of the eight-day "Healing Depression Vipassanā Meditation Retreat in Winter Solstice 2019", at the meditation hall (Figure 1) of Gengxiang Monastery 耕香寺, during the question and answer session after the Dharma talk on Anandabhaddekarattasuttam, Yaqi, a female meditator, shared shyly about her observed body sensation: "Something is suppressing. [I can] feel that something is causing me difficulty to breathe. It makes me feel very uncomfortable. Something is suppressing [in the body]."

"Did you feel this after you arrived here? Or did you experience it before?" asked with a caring tone by Wuyou, a 40-year-old Chinese Buddhist monk, one of the monastic meditation teachers of this retreat.

"A long time ago I had this experience. Recently it happened again. During the body scan exercise yesterday, while [I was] scanning around the neck area, and observing the throat internally and externally ... " Yaqi replied with a low and depressed voice.

"A feeling of suppression?" asked Wuyou.

"Yes, a feeling of suppression." Yaqi confirmed.

"Being aware of this feeling. Don't resist it. Notice it gently. As you feel the uncomfortable sensation, you can send loving-kindness to it. Relax it slowly. 
Allow it to be there. Don't resist it. You may have experienced this feeling previously. After you have come here, the feeling has become clear. The body situation manifested. Do you understand? Just notice it and continue to experience it. Remind yourself to relax." Wuyou replied gently.

"Yes, thank you."

"With continuous practice, accept any change. It's not possible that it would disappear quickly. We firstly allow and accept this suppression feeling. Then [we] try to choose. It's not necessary to urge yourself to change it. This is important." Wuyou patiently explored the body sensation of Yaqi and gave her clear instructions of dealing with it. Immediately after that, another lady raised another question about her experience of practice.

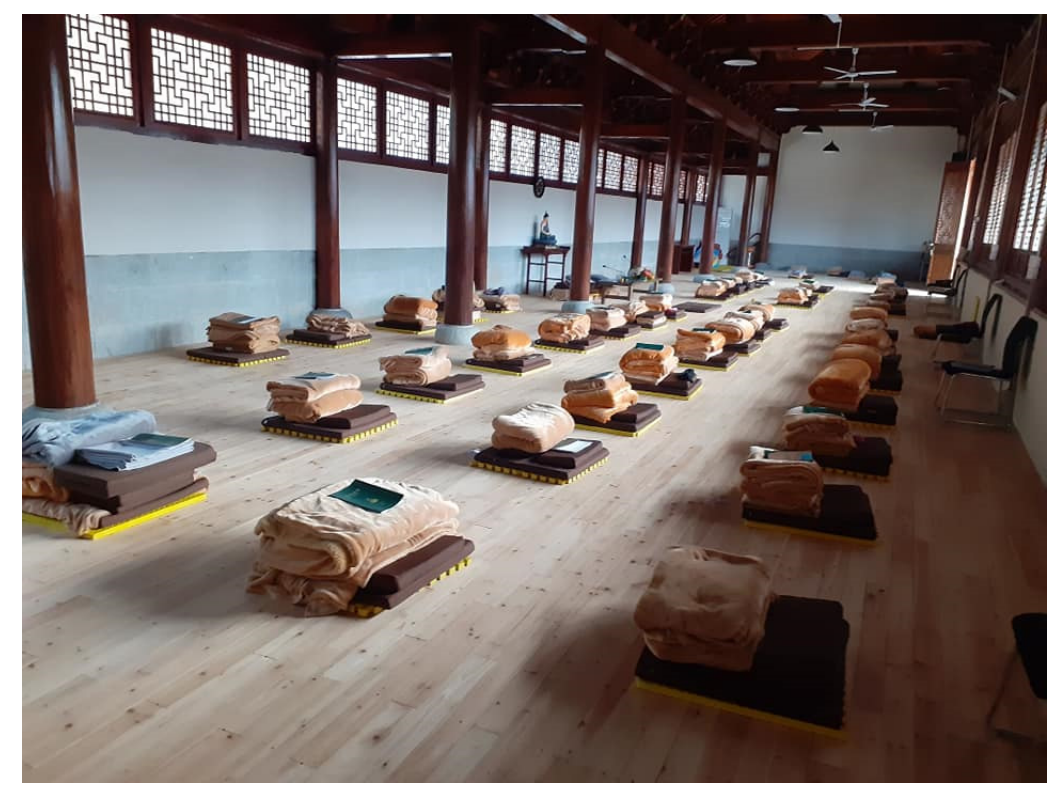

Figure 1. Meditation hall.

Unlike those seven-day meditation retreats (Chanqi 禪七) of traditional Chan school (Chan zong 禪宗), promoting a "special transmission outside the scriptures" (jianwai biechuan 教外別傅) and “not establishing upon words and letters" (buli wenzi 不立文字) with teaching style of physical "shock tactics" (Hershock 2019), various transnational meditation practices, such as vipassanā (neiguan 内觀) and mindfulness practices (zhengnian chanxiu 正念禪修), mind-body physical and psychoanalytic exercises were the focus of this eight-day vipassanā meditation retreat at this Han Chinese Buddhist monastery.

Wuyou is not the only Han Chinese monastic who teaches lay people about vipassanā meditation in mainland China nowadays after learning various meditation practices in Southeast Asian countries. By searching the Chinese term "vipassanā meditation (neiguanchanxiu 内觀禪修)" on baidu.dom, one of the most popular search engines in mainland China, there are 269,000 items found. ${ }^{1}$ Since the turn of the century, an increasing number of Han Chinese Buddhists including monastics and lay people have traveled to Southeast Asian countries to learn various meditation practices, including samatha and vipassanā meditation (Lau 2020a). Some have chosen to stay at meditation centers in Asia as ordained monastics in Theravāda traditions or lay meditators. Some meditators returned

1 Baidu.com https: / / www.baidu.com/s?ie=utf-8\&f=8\&rsv_bp=1\&rsv_idx=1\&tn=baidu\&wd=\%E5\%85\%A7\%E8\%A7\%80\%E7\%A6\%AA \%E4\%BF\% AE\&fenlei $=256 \&$ oq $=\% 25 \mathrm{E} 5 \% 2585 \% 25 \mathrm{A7} \% 25 \mathrm{E} 8 \% 25 \mathrm{~A} 7 \% 2580 \% 25 \mathrm{E} 7 \% 25 \mathrm{~A} 6 \% 25 \mathrm{AA} \% 25 \mathrm{E} 4 \% 25 \mathrm{BF} \% 25 \mathrm{AE} \% 25 \mathrm{E} 6 \% 2586 \% 2582 \% 25 \mathrm{E} 9 \% 25 \mathrm{AC} \% 25$ B1\&rsv_pq=a3fafc1d00016a76\&rsv_t=a5fen1UAG1K7xyZyg2cqpAB64O1uYdSc2VIU\%2B6nh1LQUvjkkQTwO\%2B77WZkU\&rqlang=cn\&rsv_ enter $=0 \&$ rsv_dl=tb\&rsv_btype $=$ t\&inputT $=720 \& r s v \_s u g 3=46 \& r s v \_s u g 1=25 \& r s v \_s u g 7=100 \& r s v \_s u g 2=0 \& r s v \_s u g 4=1257 \& r s v \_s u g=2$ (accessed on 5 February 2021). 
to mainland China organizing meditation retreats by inviting traveling gurus from Myanmar and Thailand (Lau 2021; Bianchi n.d.). Drawing from a recent ethnographic study of a meditation retreat held at a Chinese Buddhist monastery in south China, this paper examines how Chinese Buddhist monastics have promoted a hybrid mode of embodied Buddhist meditation practices, including Buddhist precepts, vipassanā, mindfulness, and modern psychoanalytic exercises for healing depression of people who are non-Buddhists. Although the retreat was held at a Chan monastery, interestingly, the traditional Chan practices were not the core elements included in the teaching. Instead, a syncretic approach of transnational mind-body practices from Theravāda traditions, mindfulness programs, and psychoanalytic exercises were introduced. Exploring the context of depression and the development of mind-body healing may give some light to this unique hybrid phenomenon in contemporary China.

\section{Depression, Well-Being, and Buddhist Practices in China}

There are more than 264 million people of all ages suffering from depression globally. ${ }^{2}$ Comorbid depression worsens the health state of people with chronic diseases (Moussavi et al. 2007). In contemporary China, depression has become a major public health issue and serious social burden, with women and the elderly as high-risk groups (Ren et al. 2020). About 173 million Chinese adults suffered from mental health problems with 4.3 million categorized as serious mental health problems (The Lancet 2015). Anthropologists pay attention to complex interactions among disease, environment, culture, and society (Singer and Erickson 2013). Medical anthropologists generally argue that collective trauma and suffering in health may be related to social suffering caused by the instability and turmoil of that given society (Kleinman et al. 1997). As Kleinman et al. (2011, pp. 1-5) demonstrate, the recent modernization of Chinese society has rendered physical and mental illness caused by the rapid change of emotional and moral lives in family and workplace, after three decades of explosive economic growth, marketization, urbanization, and rapid social change with rural-to-urban migration (Dillion 2009; Li and Rose 2017; Sun 2004). Suicide, resulted from depression, has been recognized as an obvious modern problem in China caused by disappointment and frustration towards family politics, social conflicts, insecurity, and injustice (Perry and Selden 2010, pp. 19-28; Wu 2010, 2011). ${ }^{3}$

Nevertheless, unlike the case in the West, depression was not perceived as a clinical disease until the 1990s in China (Lee 2011, p. 177). Currently, there is a lack of mental health physicians and services in the country (Liang et al. 2018). Kleinman (1986) argues that neurasthenia and depression in Chinese society is a culturally particular illness caused by the traditional Confucian cultural norms, which suppressed distressing emotions. ${ }^{4}$ People in the West generally categorize minor mental problems (MMPs), such as anxiety, worry, and depression, as individual sickness seeking professional medical needs (Kolstad and Gjesvik 2013). However, many Chinese perceive them as common daily life problems caused by unsatisfactory lifestyle and inharmonious relationships, especially in the family with Confucian hierarchy values. ${ }^{5}$ From a recent qualitative study, urban educated Chinese who identified the traditional and collectivistic Chinese values tended not to label MMPs as psychiatric disorders or illnesses but as challenges in daily

2 World Health Organization (2020). Available online: https://www.who.int/news-room/fact-sheets/detail/depression (accessed on 7 February 2021).

3 Suicide rate in China, especially in rural areas, is one of the highest in the world (Wu 2011, pp. 213, 234). See Perry and Selden (2010) about issues of social conflicts including labour issues, land disputes, hukou system, birth control policy, and marriage. Wu (2010) argues that, from his study, although most suicide cases were caused by family problems or domestic injustice. Yet there was notable public injustice. Some murders also happened as frustration and revenge against social injustice (Steinmuller and Wu 2011).

$4 \mathrm{Wu}$ (2011) points out that family tensions have been intensified with growing individualism and changing social structure. For example, a young wife needs to cope well with her husband, parents-in-law, and children at the same time to maintain a peaceful family life. A husband can be trapped in a complicated situation in a family with financial and health crises (p. 233).

5 Minor mental problems are defined as anxiety, worry, headaches, depression, prolonged mourning, and insomnia, etc. Among relationships in Confucian culture in Chinese society, there are five ethical relationships (wulun 五倫): ruler/minister, elder brother/younger brother, husband/wife, and friend/friend. It is believed that the family relationship is the key of a stable society (Kolstad and Gjesvik 2013). 
life only (Kolstad and Gjesvik 2014). Yet those who had a stronger sense of a bicultural self would tend to perceive MMPs with a Western medical model as diseases. This may facilitate those from the urban middle classes to explore Buddhist meditation mixed with psychotherapy, as discussed later.

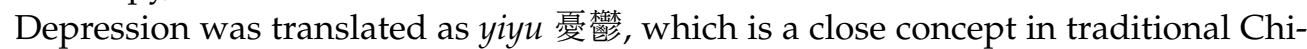
nese medicine. $Y i$ means worry. $Y u$ refers to "stagnation", meaning life-energy $q i$ 氣 "not flowing" and "blocked" (Ng et al. 2006). Emotional stagnation, for example, repressed anger or anger stagnation, commonly causes mind-body dysfunction, including sleeping disturbances and feeling of obstruction in swallowing and indigestion. ${ }^{6}$ Although there are common clinical features between stagnation and depression, such as dysphoria, obsessive preoccupations, and somatic obstruction symptoms (e.g., "I feel as if there is something obstructing my throat"), they are differentiated psychometrically. "Strong feelings of guilt, self-rejection, worthlessness, and helplessness" are features that mainly attach to depression (Ng et al. 2006, p. 480). "Overattachment and feelings of obstruction or inhibition" are features mainly manifest in stagnation ( $\mathrm{Ng}$ et al. 2006, p. 480). In the traditional Chinese medical context, somatic stagnation can be treated with "de-stagnation of qi" with herbal medicine, acupuncture, and letting go of overattachment by learning Buddhist practices (Ng 2003, p. 112; Ng et al. 2006), which guide a path towards detachment and liberation. Hence, instead of medicalization of life problems seeking help from physicians or clinical psychologists, Chinese who identify traditional Chinese values may tend to deal with their unsatisfactory daily life problems in various ways, such as mind-body qigong 氣 功 practices, and embodied religious and spiritual practices.

For example, from a recent study of a lay Buddhist community in Beijing, Buddhist practices become a means for the marginalized, such as laid off workers and migrant workers, to regain a respected status and identity from their unsatisfactory social life. ${ }^{7}$ Devotees committed to Buddhist texts circulation, Buddhist rituals, and Chan meditation practices in an imagined community (Fisher 2011). Urban Buddhists in contemporary China tend to interpret Buddhism from their own personal experience and their own needs (Yao and Badham 2007). By comparing religious practices in rural and urban areas, Fan (2003) concedes that the recent trend of religious privatization and individualization in urban areas shows a yearning of city dwellers in search of spiritual meaning from various embodied religious or spiritual practices, such as qigong and meditation.

Bringing awareness to the relationship between health and well-being through body practices is one of the core ideals of the good life (xingfu 幸福) in Chinese culture (Chen 2001). Mind-body practices for healing have been practiced for centuries and reinvented in modern China. For example, a modernized form of qigong was reinvented as simple gymnastic methods in Hebei in the 1950s. Then, the "qigong fever" since the 1980s has provoked the popularity of body technology for healing, religion, and ancient culture (Palmer 2007, pp. 1-5). Every morning, millions of Chinese practiced various kinds of qigong to cultivate life energy $q i$ in shared urban spaces, such as the squares, parks, trees, and open spaces for communal healing in cities (Chen 2001; Palmer 2007). After "qigong fever", since the turn of the century, health cultivation (yangsheng 養生) culture has been popular in mainland China (Dear 2012). Based on the core philosophy of enhancing one's vitality or qi originating from the third century, yangsheng aims at self-regulation of an individual body with daily body activities, including exercises, balanced lifestyle, nutrition, and Chinese medicine. The fashion of yangsheng reflects the quest for health identity with the success of economic power of the newly wealthy urban middle classes.

It is significant to note that this new emerging trend of privatized mind-body healing has impacted Buddhist practices to be re-invented, re-developed, and even imported in mainland China. With the influence of martial arts films, such as Shaolin gongfu 少林 功夫 in the 1980s, “Chan fever" (chanxuere 禪學熱) aroused popular interest in Buddhist

6 In traditional Chinese medicine, "repressed anger" is seen as a common cause of stagnation (Ng et al. 2006, p. 481). Moreover, fear is the "mother" of anger and an underpinning emotion of stagnation (Chan et al. 2002).

7 Those devotees include laid-off workers, the retired, migrant workers, patients with mental illness, etc. (Fisher 2011). 
tourism, practicing Chan meditation and well-being (Ji 2011). From my fieldwork, among monastics, lay Buddhists, or even tourists, there is a general great interest in learning Chan school (Chan zong 禪宗) meditation practice or those fascinating master-student encounters, "public case" (gongan 公案) stories of enlightenment. Despite the Open Policy and Buddhist revival ${ }^{8}$ in the 1980s, it has not been easy to revive the Chan school practices due to a lack of prominent Chan meditation teachers with the generation gap in monastic lineages in the past few decades. ${ }^{9}$

Although the seven-day meditation retreats (chanqi) of traditional Chan school have been redeveloped in those renowned historical Chan monasteries, such as Nanhua Monastery 南華寺 and Yunmen Monastery 雲門寺, many Chinese monks could not understand the traditional Chan practices and rituals, for example, huatouchan 話頭禪 or kanhua chan 看話 禪, a practice on an internal investigation through mindful concentration on a key phrase, developed by Dahui Zonggao 大慧宗某, an influential Chan master in Song dynasty. ${ }^{10}$ Lay people also find it difficult to understand the classical language and practices of Chan school. More importantly, chanqi are practiced by monks or male lay only at monasteries in mainland China. This traditional ritual rejecting female entering Chan meditation halls (chantang 禪堂) of monasteries nowadays has encouraged nuns and female Buddhists to explore alternatives of spiritual seeking. ${ }^{11}$ To save the Chan lineage, Jinghui started organizing “life Chan summer camp" (shenghuochan xialingying 生活禪夏令營) in 1993， targeting university students so that young males and females had opportunities to explore Buddhist ethics and a taste of meditation (Ji 2011).

With economic booming, the relaxing policy of tourist policy, the influences of Buddhist modernization in the Southeast Asia, and globalization ${ }^{12}$, experienced Chinese Buddhists, including monks, nuns, laymen, and laywomen started traveling to Southeast Asia to learn meditation practices in Theravāda traditions since the century turn (Lau 2020a; 2021). Despite the challenges of visas application, language barrier, and diet, experienced meditation teachers, the ideal environment of meditation centers, and a spacious living area for individuals are much more attractive compared with traditional esoteric practices and rituals (Lau 2017). More significantly, Chinese nuns and laywomen enjoy equal opportunities of learning meditation with meditators from different countries at international meditation centers as monks and laymen do.

Various kinds of transnational meditation teachings from Myanmar and Thailand have been spread to China by travelling gurus and returning meditators, including monastics and laypeople, in the past decade. The ten-day vipassana meditation with Goenka's teaching in 1999 may be the first transnational meditation transplanted in contemporary China $^{13}$ (Lau 2020a, pp. 116-17). Despite the restriction of religious activities by the partystate policy, these meditation retreats have attracted mainly the educated middle class,

8 In the early 1980s, Buddhist monasteries, especially historical ones, were reconstructed with the state support and funding through transnational networks of overseas Chinese communities. See Ashiwa and Wank (2005).

9 After eminent Chan monks, such as Laiguo 來果 (1881-1953) and Xuyun 虛雲 (1840-1959), passed away, the monastic lives of the next generation of disciples, such as Foyuan 佛源 (1923-2009), Jinghui 淨慧 (1933-2013), and Delin 德林 (1914-2015), were disrupted due to the political turmoil since the 1960s. For example, Jinghui was forced to leave his monastery to a remote village for labor work in Guangdong Province.

10 The comments about the general lack of knowledge of Chan practices of Chinese monks is from my fieldwork and interview with an abbot of a Chan monastery (Lau 2018). More details about development of kanhua chan, see Chapter 3 Procreation and Patronage in the Song Chan School (Schlütter 2008, pp. 55-77). From a search of Chinese Buddhist texts via CBETA, the term huatouchan 話頭禪 is used in ancient texts, for example, Quotation of Chan master Xueguan 《雪關禪師語錄卷之七》 (CBETA 2019.Q4, J27, no. B198, pp. 487c29-488a1). Yet kanhua chan 看話禪 is found only in L ü cheng 呂溦 (1896-1989) Introduction of the Historical Sources of Chinese Buddhism 《中國佛學源流略講》(CBETA 2019.Q4, LC02, no. 2, p. 401a2-4).

11 From my fieldwork, the only exception is Gaomin Monastery 高旻寺 at Nanjing 南京. After the revitalization of the monastery, Delin, a disciple of Laiguo, allowed nuns and lay women practicing Chan retreats at the Chan hall. I visited Gaomin Monastery for joining the Chan retreats in 2006 and 2007 (Lau 2018).

12 About Buddhist modernism and globalization, see McMahan (2008, 2017); about Buddhist modernization in Republican China, see Lau (2020a).

13 In 1999, the first ten-day vipassanā meditation retreat in China was held at Bailin Monastery 柏林寺, where Jinghui was the abbot (see Lau 2018; Lau 2020a, pp. 116-17). 
university students, and professionals (Lau 2017). ${ }^{14}$ Learning transnational meditation from famous teachers has become trendy among urban people. Mind-body healing in particular is one of the key attractions to the new types of meditation. From my fieldwork and analysis, the existing lay meditation activities in contemporary China can be divided into four main models. The first model is meditation retreats in one tradition held at Han Chinese Buddhist monasteries. ${ }^{15}$ The second model is retreats in various traditions held at Han Buddhist monasteries. ${ }^{16}$ The third model is a Theravāda Buddhist community built. ${ }^{17}$ The fourth model is meditation retreats held at secular venues. ${ }^{18}$

Wuyou, originally from Hubei Province, was educated with a mixed background of counselling, traditional Chinese Buddhism, and transnational Buddhist meditation. He has involved himself in the second model by organizing more than ten meditation retreats over the past few years. After completing a bachelor's degree in social work followed by four-year study at a Buddhist studies academy (foxueyuan 佛學院) at Suzhou, Wuyou studied one year at the International Theravāda Buddhist Missionary University in Yangon in 2009. ${ }^{19}$ He started exploring vipassanā meditation in Myanmar. After returning to China, he became a teacher at a Buddhist studies academy in Jiangxi and assisted in organizing a fewvipassanā meditation retreats by inviting renowned international meditation teachers from Myanmar, for example, U Pandita Sayadaw (1921-2016), Chanmyay Sayadaw (1928-), U Ñānaramsi Sayadaw (1960-) from the lineages of Mahāsi Sayadaw (1904-1982), and U Tejaniya Sayadaw (1962-). After ordaining at Yangon as a Bhikkhu in 2016, Wuyou started teaching meditation at Buddhist academy. Since 2018, he has moved to Gengxiang Monastery, a re-built Chinese Buddhist monastery in Jiangxi, organizing and teaching regular vipassanā meditation (neiguanchan 内觀禪) retreats for lay people.

Despite his rich experience of organizing vipassanā meditation retreats in Chinese Buddhist communities, this was the first time that Wuyou was targeting lay people with depression explicitly. On the on-line registration form, four kinds of participants were targeted: those with mild or moderate depression, those who are easily depressed and emotional, those feel stressed in daily life and have difficulty managing emotion, and those who are interested in a regulating emotion and spiritual group. ${ }^{20}$ Applicants were restricted to those over 18-year-old without violence, suicidal, and self-harming behavior in the camp. Additionally, applicants had to declare their mental condition, history of seeking clinical support, and drugs they were taking. Participants were recommended to bring along their own drugs. While non-Buddhists were welcome to submit the application, on the application form, they should promise to respect the three triple gems (the Buddha, the Dhamma, and the Sangha) and observe the retreat schedule (see Tables 1 and 2) and regulations, including following the law of the country, observing the Buddhist precepts and silence, serving the community with daily chores, and taking food and using resources mindfully. ${ }^{21}$ There was no charge for the teaching. On arrival, participants were invited to leave their mobile phone at the office and support the community by making a donation to the monastery for the cost of food and accommodation. ${ }^{22}$

14 Due to the Regulations on Venues for Religious Activities issued firstly in 2004, all religious activities are restricted to religious venues only (Ji 2011). From my fieldwork, ten-day retreats of Goenka's tradition held at hotels were interrupted. The official maximum number of participants of religious activity is fifty only. See an example in Lau (2017, p. 320).

15 For example, for the first model, retreats of Goenka's teachings which are organized at five main centres at Chinese Buddhist monasteries (Lau 2018) and Mahasati meditation of Luangpor Teean from Thailand organized at Shifosi 石佛寺 in Sichuan Province (Bianchi n.d.).

16 For the second model, retreats of some teachings, for example, of Mahāsi Sayadaw, U Tejaniya Sayadaw, and Luangpor Pramote are held at different monasteries across the country (Lau 2018).

17 For model three, Dhammavihārī Forest Monastery, established as a permanent meditation center, mainly promotes the teaching of Pa-Auk Sayadaw (for details, see Lau 2018, pp. 126-89).

18 Some vipassanā retreats and mindfulness programs were held at universities, yoga clubs, restaurants, or resort centers.

19 The background information of Wuyou is found on the online registration form of the "Healing depression Vipassanā Meditation Retreat in Winter Solstice 2019". Available online: https:/ /jinshuju.net/f/G2KzuH?from=singlemessage (accessed on 7 February 2021).

20 Ibid

21 Ibid.

22 Participants were suggested to make a donation of RMB800 for the cost of food and accommodation, as written on registration form, ibid. 
Table 1. Daily schedule of Healing Depression Vipassanā Meditation Retreat at Gengxiang Monastery in Winter Solstice 2019.

\begin{tabular}{|c|c|}
\hline Time & Activities \\
\hline $5: 10$ & Wake up \\
\hline $5: 10-5: 50$ & Brushing teeth and getting ready \\
\hline $5: 50-6: 20$ & Swing hands exercise (Pingshuaigong 平甩功) \\
\hline $6: 20-7: 00$ & $\begin{array}{l}\text { Sitting meditation } \\
\text { Morning chanting and requesting Nine Uposatha Precepts (cixinjiujie 慈心九戒) }\end{array}$ \\
\hline $7: 00-8: 20$ & Breakfast and Mindful chores \\
\hline $8: 30-9: 30$ & Sitting meditation \\
\hline 9:30-10:00 & Walking meditation \\
\hline 10:00-11:00 & Mindful psychological exercises \\
\hline 11:00-11:30 & Walking meditation \\
\hline $11: 30-12: 30$ & Lunch \\
\hline 12:30-13:45 & Rest \\
\hline 14:00-14:30 & Walking meditation or Group interview \\
\hline 14:30-15:30 & Sitting meditation or Group interview \\
\hline 15:30-16:30 & Walking meditation or Group interview \\
\hline 16:30-17:00 & Sitting meditation \\
\hline 17:00-18:00 & $\begin{array}{l}\text { Mindful drinking sugar water } \\
\text { Bathing }\end{array}$ \\
\hline 18:00-18:30 & Mindful yoga \\
\hline 18:30-19:00 & Walking meditation \\
\hline 19:00-20:00 & Teaching meditation practices \\
\hline 20:00-20:30 & Walking meditation \\
\hline 20:30-21:00 & Sitting meditation \\
\hline 21:00-21:30 & Evening chanting \\
\hline
\end{tabular}

Table 2. Themes of mindful psychological exercises and meditation practices teaching.

\begin{tabular}{lcc}
\hline Day & Mindful Psychological Exercises & Teaching Meditation Practices \\
$\mathbf{1 0 : 0 0 - 1 1 : 0 0}$ & - & $\begin{array}{c}\text { 19:00:00 } \\
\text { Welcoming speech, regulations, and } \\
\text { schedule; body scan practice }\end{array}$ \\
\hline $\mathbf{1}$ & $\begin{array}{c}\text { Teaching sitting and walking meditation } \\
\text { Mindful eating with raisin }\end{array}$ & $\begin{array}{c}\text { Dharma talk on Ānandabhaddekarat } \\
\text { tasuttam } \\
\text { (Yiyexianzhejing } \text { 夜賢者經) }\end{array}$ \\
\hline $\mathbf{2}$ & Mindful talking practice & Awareness of thoughts and emotions \\
\hline $\mathbf{3}$ & 3-min breathing space exercise & Awareness of five senses and pain \\
\hline $\mathbf{4}$ & Exercise with symbols & Five hindrances \\
\hline $\mathbf{5}$ & Self-exploration with inner child exercise & Right thought and Four Sampajañna \\
\hline $\mathbf{6}$ & Loving-kindness exercise & Loving-kindness practice \\
\hline $\mathbf{7}$ & Cultivating forgiveness exercise & Depression symptom and treatment \\
\hline $\mathbf{8}$ & Closing ceremony and Mindful sharing & - \\
\hline
\end{tabular}




\section{Mind-Body Training with Precepts and Vipassanā Meditation}

On the first evening of the retreat, all participants were sitting on meditation mats quietly at the meditation hall after settling down from their long distance travel from different provinces. Wuyou and Jiewen, the two monastic teachers, dressed in Chinese Buddhist monastic robes and pairs of eyeglasses, ${ }^{23}$ were sitting in the middle facing all participants. Behind them was a very small Sakyamunī Buddha statue in modern style and a piece of "fragrant sword" (xiangban 香板), a common symbolic instrument for keeping discipline at Chan hall (Figure 2). ${ }^{24}$ Unlike the traditional Chinese Chan hall in square size, this meditation hall is designed as a long rectangle with meditation mats on the floor. The setting emulates those halls in Theravāda tradition. Three monks, two male volunteer Dhamma workers (fagong 法工), and 10 male participants were sitting on the right wing of the hall. A nun, two female Dhamma workers, and 24 female participants were sitting on the left wing of the hall. All teachers and participants were Han Chinese.

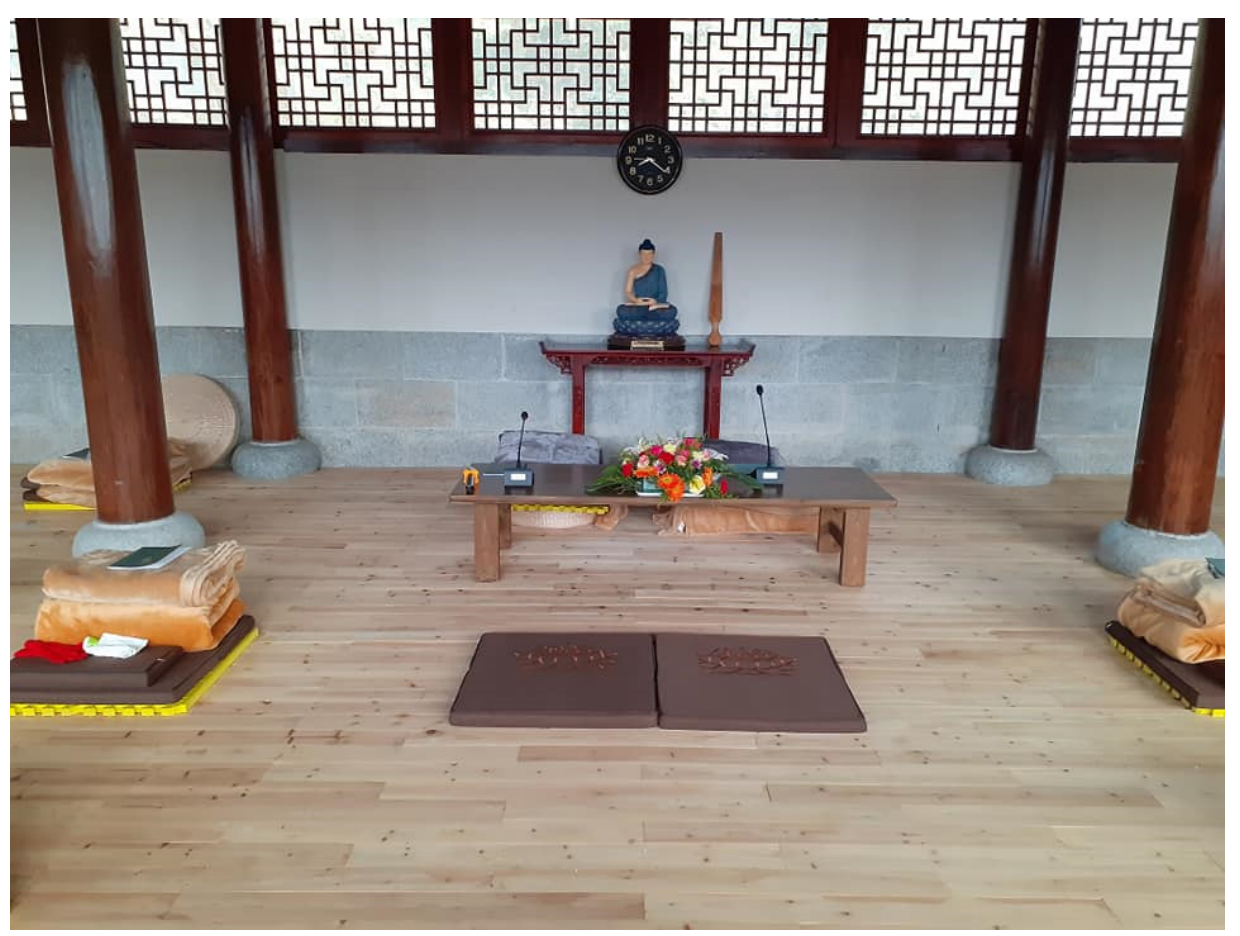

Figure 2. Fragrant sword.

Unexpectedly, Wuyou started sharing his experience of suffering from depression after university graduation. He had stayed in his own bed for about two months. He said he has not fully recovered from that until now. He experiences irregular low mood sometimes. Nevertheless, with the training of Buddhism and meditation practices, he could handle his emotions and thoughts. He reminded the participants to learn the practices in the retreat with a beginner's mind (chuxin 初心) without any expectation of results, just like primary school students exploring the world with curiosity. The term "beginner's mind" was popularized by Shunryu Suzuki, a modern Japanese Buddhist Zen Master in the West

23 Wuyou, who was ordained in Myanmar again in 2016, dressed in Burmese monastic robe in 2017 when he visited Hong Kong. From my fieldwork, there were Chinese monks wearing robes in Theravāda traditions after returning to the country (see Lau 2020b). Yet, it may be a bit politically sensitive to dress in other traditions in Chinese Buddhist monasteries in the past few years rencently with a more strict regulation of organizing religious activity.

24 From my fieldwork in Hong Kong and mainland China, the fragrant sword is still used nowadays by Buddhist monastics at traditional Chan hall for hitting those meditators who violate the rules at Chan hall, such as drowsiness, talking, and making noise. I had shocking experiences of being hit for mild drowsiness and improper sitting posture at the Chan hall at Gaomin Monastery at Nanjing. At another Chan monastery, an old lady showed grievances by shouting at a Buddhist monk who hit her for sleeping with groaning noises and expelling her from the Chan hall. 
in the 1970s, with his famous book Zen Mind, Beginner's Mind (Suzuki [1970] 1995). ${ }^{25}$ Inspired by Suzuki, Jon Kabat-Zinn, who has developed secular mindfulness programs in the 1980s, highlights "beginner's mind" as one of the seven important attitudes in practicing mindfulness. ${ }^{26}$ Wuyou then explained to the participants about the significance of training the body through observing the Buddhist precepts to establish mindfulness and wholesome mental states.

In the Buddhist perspective, observing precepts (sila; jie 戒) as training the body is an ethical foundation of training the mind to limit the body impulses of lust, desire, or thirst ( $\tanh \bar{a}$; $\tan$ 貪), which are the main causes of suffering (Collins 2000). Like many Indian spiritual practices, Buddhist monastic training attempts "to control and finally eliminate bodily drives and affects" (Collins 2000, p. 185), not only to maintain an order of human social life, but also to attain the final goal of nibbana, an extinction of all defilements and suffering. To both monastics and lay people, through regulation of the body by observing precepts, virtuous and wholesome behaviors in the aspects of body, speech, and mind can be established. In other words, unwholesome behaviors can be avoided. ${ }^{27}$ For examples, there are five basic Buddhist moral precepts for all human beings: not killing, not stealing, not having sexual misconduct, not telling lies, and not taking intoxicants. The third is to refrain from kāmesu-micchācāra, "wrong behavior in regard to (sense-) desires" (Collins 2000, p. 189). To monastics, sexual behavior is absolutely prohibited. ${ }^{28}$ To lay people, adultery should be prevented. Wholesome and unwholesome behaviors are defined clearly in details in Vinaya, the text of all Buddhist precepts and procedures that govern the Buddhist monastic community.

The revival of the Buddhist monastic disciplines (vinaya; jielu 戒律) is a feature in modern and contemporary China (Bianchi 2017). Observing precepts is a prerequisite training for practicing meditation in both Theravāda (Cook 2010) and Mahāyāna traditions. In the Theravāda tradition, the eight precepts (atthanga-silla) are observed by laity on the Uposatha day, such as new moon and old moon days at meditation centers or monasteries in Thailand and Myanmar. In contemporary Chinese monasteries, lay people practice the similar eight precepts (baguan zhajie八關齋戒), refraining from killing, stealing, sexual activity, wrong speech, taking intoxicants, eating after noon, entertainment, and sleeping in a luxurious bed ${ }^{29}$. In the Mahāyāna Chinese context, however, as I explored, observing the precept of refraining from food in the afternoon is generally less strict compared with the Theravāda context in Southeast Asia. ${ }^{30}$

In this retreat, nonetheless, instead of the eight precepts, participants were invited to request the Nine Uposatha precepts (cixin jiujie 慈心九戒) every early morning after exercise and sitting meditation (see Table 1). After chanting the three-fold refuge ${ }^{31}$ and the eight precepts in both Pāli and Chinese, participants chanted the ninth precept on loving-kindness with "may all beings be free from enmity, be free from mental sufferings, be free from physical sufferings, and take care of themselves happily." While the eight precepts are external rules, the ninth precept is an internal training. With the cultivation of kind thoughts towards oneself and others in every morning, participants then learned the loving-kindness meditation on Day 6. Loving-kindness (mettā; cixin 慈心) is one of

25 David McMahan (2008, p. 8) categorizes Shunryu Suzuki as a figure of modern Buddhism.

26 Kabat-Zinn acknowledged Shunryu Suzuki in his first book Full Catastrophe Living (Kabat-Zinn [1990] 2005, p. xxi). About discussion of the beginner's mind, see Kabat-Zinn [1990] (Kabat-Zinn [1990] 2005, pp. 31-46).

27 There are 227 Vinaya precepts for Buddhist monks, 311 for nuns, and 75 for trainees related to their "dress, deportment, and etiquette", and food taking in daily life (Collins 2000, p. 198). The number of precepts may be different in different sects due to historical development.

28 Monastic members are expelled from the community for any form of sexual intercourse (Collins 2000, p. 189)

29 For example, participants recite "I undertake the training of refraining from killing the living beings", see details https://www. buddhistgroupofkendal.co.uk/navanga-uposatha-nine-uposatha-precepts/ (accessed on 5 February 2021).

30 As I experienced in a few retreats in the Mahāyāna Chinese Buddhist context, oat porridge, milk product, or even rice are allowed after noon. Yet, only clear liquid is allowed in most Theravāda meditation centers.

31 Three refuges refer to the Buddha, the Dhamma (the truth), and the Sangha (Buddhist monastic community). For example, "I go to the Buddha for refuge." 
the four "Divine Abidings"32 or "immeasurable meditation" (Anālayo 2020b) that bring heavenly happiness (Collins 2000, p. 196). According to Buddhist texts, those who practice loving-kindness can receive eleven benefits, including sleeping easily, waking up happily, sleeping without evil dreams, being loved by people, and being protected from poison and weapons. ${ }^{33}$ More importantly, the practice is beneficial of healing depressed and anxious state filled with negative thoughts, aversion, and hatred. As explained by Wuyou, with loving-kindness cultivated in the mind, hatred towards oneself and others can be reduced or transformed.

On Day 2, Wuyou gave teaching by introducing various practices of vipassanā meditation (neiguanchan 内觀禪), including sitting meditation, walking meditation, and daily life practices. He firstly explained that the term "meditation" (chanxiu 禪修), translated from bhāvana, means cultivation or development. Buddhist meditation is about cultivating wholesome (kusala) mental qualities, such as mindfulness, effort, calmness, wisdom, and faith with embodied practice. In contrast, it also aims at eliminating those unwholesome (akusala) mental qualities, such as desire, hatred, doubt, and delusion, which induce mental suffering, such as anxiety and depression. In the general Chinese Buddhist context, meditation is always associated with an image of a monk sitting calmly with a full-lotus posture. Nevertheless, Wuyou clarified, "meditation is not about practicing in sitting posture only, or any specific posture, or at specific location. When you are walking, sweeping the floor, drinking, or eating, you can be aware of your mind, whether there is desire, hatred, and delusion."

Vipassanā, which means "insight meditation", is a contemporary form of meditation modernized by Ledi Sayadaw, a meditation teacher and Buddhist scholar in Burma (Braun 2013). Facing the crises of Buddhism due to British colonialism, Ledi simplified the Abhidhamma by placing more emphasis on vipassanā meditation rather than samatha meditation, cultivation of mental absorption (jhanna). In 1948, with the support of the first prime minister, $\mathrm{U} \mathrm{Nu}$, who sought to establish Myanmar as a Buddhist country, Mahāsi Sayadaw further promoted and revitalized vipassanā as a transnational meditation practice. This has evoked a massive increase in lay people learning meditation in Burma ${ }^{34}$, and later in Asia and the West (Cook 2010; Lau 2021, p. 189). Since the 1970s, S.N. Goenka (1924-2013), who defines vipassanā as a universal, scientific, and therapeutic technique, has established over 300 centers in the world, and over five centers in mainland China. Goenka emphasized that the main goal of vipassana $\bar{a}$ practice was to cease suffering and attain final liberation through understanding the Dhamma, the law of nature in the mind and body. Although Goenka claims that vipassana is a teaching passed down from the Buddha, he has promoted the practice as a non-religious and secular practice, which could benefit anyone from any religious or social background. Western meditators visited Myanmar and Thailand in the 1960s for learning various meditation practices. The transnational lay meditation movement, which started in Southeast Asia, spread to the West in the 1970s, and was brought back to East Asia in the recent decade. ${ }^{35}$ With Buddhist revival and economic booming in China, various transnational vipassana teachings, including the Burmese traditions (Lau 2020a) and Thai traditions (Bianchi n.d.; Lau 2020b), have been introduced in the mainland since the turn of the century.

From his rich experience of practicing and teaching vipassanā meditation, Wuyou introduced three key elements of the practice. The first is about keeping right attitudes by accepting the mind and body experiences without desiring any results from the practice. He explained, "when one is depressed, the whole world is in grey. At this moment, it is important to accept that uncomfortable body sensation and low mood as an observer. Be aware of it. Allow the mind-body condition as it is. Once you have comfortable feeling

32 The other three are compassion, sympathetic joy, and equanimity.

33 AN 11.16.

34 Over 300,000 were educated with Abhidhamma by Ledi's efforts between 1903 and 1926 (Braun 2013).

35 See Lau (2021) for the details of pilgramage and establishment of transnational meditation networks. 
without awareness, you would attach it easily. So don't try to control anything. Don't try to pursue any goal. Be mindful."

The second key element is about bringing awareness to the mind-body experience in a relaxing way. "Now put your palms together. Can you feel the touching sensation? Do you need effort to know that? Can you feel your bottom touching the mat? Do you know the breath? Can you hear me?

This is awareness, about relaxingly knowing. If you use force, it would be exhausting, then you can keep the awareness continuously." The third is about bringing awareness to the mind and body all the time. "Once the awareness run away, start again. You can start again anytime. It doesn't matter when you forget the practice. It is not necessary to think about depression. Just experience it." He finally tried to summarize the definition of vipassana in one sentence, "neiguanchan is being aware of the present mind-body experience relaxingly with observer's perspective, and allowing it as it is. The practice can start again anytime."

The vipassanā practices highlighted by Wuyou have no difference from satipațthāna practices introduced in the Discourse on Establishment of Mindfulness (Satipatthāna Sutta) and Discourse on Mindfulness of the Body (Käyagatāsati Sutta). ${ }^{36}$ Body is the primary focus of the practices (Anālayo 2020b),

Mindfulness of breathing,

Mindfulness of the four postures,

Mindfulness and clear knowing during various bodily activities,

Mindfulness of the anatomical constitution of the body,

Mindfulness of the physical constitution of the body,

Mindfulness of the decay of the body after death,

Mindfulness of the bodily dimension of the experience of the four absorptions.

As illustrated by Anālayo (2016), the instruction of the discourse is about knowing the type of feeling when it manifests at that present moment, for example, "I feel a pleasant feeling" or "anger is present within me". Another important dimension of the practice is to recognize the body sensation and feeling mindfully. It is crucial to be with the experience "without immediately reacting with likes and dislikes" (p. 1275) so that further mental suffering would not be created by desire or aversion. The continuous mindfulness practices can result in reducing the reactions towards negative thoughts and emotions that induce fear, anxiety, and depression. In this retreat, the practices of observing precepts and vipassanā meditation through the body follow the satipatthanna practices in early Buddhism.

\section{Mindfulness Practices for Overcoming Illness and Depression}

While depression is one of the most common mental health problems nowadays, it is often comorbid with other physical and mental diseases (Moussavi et al. 2007). Comorbidity with depression significantly worsens the health state of people with chronic diseases. ${ }^{37}$ The contemporary evidence of embodied depression and mental suffering support the early Buddhist perspective of a non-dualistic body-mind relationship. Bodily inflicted harm is ultimately caused by harmful mental intention (Anālayo 2020b). Healing physical and mental suffering with the role of the body as an object of mindful contemplation is discussed in Buddhist texts.

In both Theravāda and Mahāyāna Buddhist traditions, the Buddha demonstrated to his disciples how he had overcome illness and pain with mindful contemplation of the body. ${ }^{38}$ In the ancient context, the Buddha was a role model of self-healing

MN 119 and MĀ (T 81).

37 In this study, the mean health score of all comorbid depression is lower than for any of the chronic conditions alone (angina, arthritis, asthma, and diabetes) or for depression alone (Moussavi et al. 2007).

38 See Salguero (2015) about the global history of Buddhist healing. Tibetan medicine and other Asian medical practices are discussed in modern context (Connor and Samuel 2000). In the Chinese context, Buddhist healing started in medieval China (Salguero 2013). 
and overcoming illness. On one occasion, the foot of the Buddha had been hurt with strong pain. It is described that the Buddha faced pain with mindfulness and concentrated mental condition (Anālayo 2016) ${ }^{39}$. In the early Buddhist texts, ${ }^{40}$ on another occasion when the Buddha was sick, he laid down and asked his close disciple Ānanda to proclaim the seven factors of awakening for overcoming illness and bearing extreme pain, with mindfulness, investigation-of-dharmas, energy, joy, tranquility, calmness, and equanimity (Anālayo 2015, pp. 24-25). After that, the Buddha was able to sit up straight with the established mindfulness. The following poem describes the Buddha's recovery:

Hearing the awakening factors being proclaimed

Thoroughly experiencing the flavor of full awakening,

[Although] the body had been afflicted by great pain

[The Buddha] endured the illness and sat up straight to listen. ${ }^{41}$

Mindfulness (sati; zhengnian 正念) takes a significant role in cultivating awareness and developing the other six awakening factors for alleviating afflictions. Once, when Ānanda, a disciple, was worried and anxious for the very sick body of the Buddha, the Buddha guided him to practice mindfulness as a means of self-reliance (Anālayo 2015). As stated in the Discourse on Mindfulness of the Body, by cultivating an embodied type of mindfulness, one benefit from overcoming fear, anxiety, and depression, bearing with bodily afflictions caused by weather, hunger, or thirst, and even attaining the absorption and awakening (Anālayo 2020b).

In the contemporary contexts, it shows that the modernized form of Buddhist meditation and mindfulness practices have facilitated practitioners overcoming physical and mental suffering. For example, there have been cases of healing diseases, such as cancer and pain, through vipassanā meditation in the teaching of Mahāsi Sayadaw ([1976] 2009), who contributed to the lay meditation movement in the 1960s in Myanmar (Jordt 2007). S. N. Goenka healed himself from severe migraine headaches under the teaching of $U$ Ba Khin (Goldberg 2014, pp. 80-81). Goenka further medicalized and secularized vipassanā as a universal non-sectarian teaching (McMahan 2008), pp. 185-86. Using modern scientific terms, Goenka explained that the mind and body were "nothing but subtle wavelets of subatomic particles" (Hart 1987, p. 115). The solid body was composed of tiny particles called kaläpas, which vibrated, oscillated, arose, and vanished rapidly. The root problem of human suffering was caused by taking the mind and body as a permanent entity, a self-identity that resulted in a reaction of liking and disliking. Meditators can cease the suffering by observing the impermanence of the mind and body without reacting to the pleasant or unpleasant feelings. Some Chinese meditators recently reported that their long-term physical problems, such as stomach pain, were cured after attending intensive vipassanā retreat (see Lau 2017, p. 324).

The transnational lay meditation movement in Asia not only has spread vipassanā or insight meditation to the West, but has also impacted secular mindfulness programs for promoting physical and mental health (Lau 2021). The effectiveness of the eightweek Mindfulness-based Stress Reduction (MBSR) program, developed by Jon KabatZinn $^{42}$ in 1979, in reducing symptoms of stress, anxiety disorder (Kabat-Zinn et al. 1992), and psychosomatic diseases has aroused increasing research interest on mindfulness and various diseases (Williams et al. 2013), including back pain (Doran 2014) and trauma of women (Myers et al. 2015). Mindfulness practice can effectively deal with mental suffering including fear and anxiety (Gu et al. 2015; Roy et al. 2020). Another prominent successfully developed program is the Mindfulness-Based Cognitive Therapy (MBCT) by clinical psychologists Mark Williams, John Teasdale, and Zindel Segal (Segal et al. 2012;

SN I 27.

40 This occasion was founded in both Nikāya from Pāli scriptures and āgama from Sanskrit scriptures (Anālayo 2015).

41 The text is from Samyukta-āgama at TII 195c23 to 195c24, translated by Anālayo (2015).

42 Kabat-Zinn (2011), a molecular biologist and a practitioner of Hatha yoga and Korean Zen, developed the MBSR programme at the school of medicine of the University of Massachusetts in 1979. 
Rycroft-Malone et al. 2019). MBCT has been recognized by National Institute of Clinical Excellence (NICE) as an effective practice for preventing depression relapse in the United Kingdom.

As I have examined, although mindfulness practices from these secular mindfulness programs, including mindful sitting, mindful walking, and body scan exercises, are very similar to those modernized vipassanā meditation in Buddhist tradition, they are organized in a well-structured curriculum with eight-week psycho education lessons and home practices in a group-based counselling format led by trained lay teachers in a secular context. With the main goal of healing diseases in the modern clinical and psychological context, moral precepts and any background information about Buddhism in general would not be mentioned or discussed by teachers in the class. The application of mindfulness programs in a clinical context has popularized mindfulness meditation to counselling centers, workplaces, and schools in the West and later Asia. Mindfulness programs have been brought to Hong Kong, Taiwan, and China by psychologists and some Buddhist meditation practitioners in the past decade. Jon Kabat-Zinn and Mark Williams started travelling to China by invitation to teach mindfulness meditation since 2011 (see Lau 2021). In the past few years, with the effort of some Taiwanese and Hong Kong mindfulness teachers, mindfulness programs have been popular in psychology and medical research in China (Lau 2021). ${ }^{43}$ For example, from a recent study of patients with spontaneous intracerebral hemorrhage in China, positive effects of quality of life and poststroke depression were found with the MBCT program (Wang et al. 2020). Nevertheless, research of mindfulness in health in China is still underdeveloped compared with the West.

Within this time period, there has also been criticism and debate about the popularity of secular mindfulness programs in the West (Purser 2019). One of them is about scientists and non-Buddhists appropriating mindfulness practices from the Buddhist traditions into a de-contextualized secular program without Buddhist ethical foundation (Poceski 2020). Nevertheless, unexpectedly, in this retreat at Gengxiang Monastery, Jiewen 界文, another prominent monastic meditation teacher, introduced a few mindfulness practices from the secular mindfulness programs, including body scan practice, mindful eating with raisin, and 3-min breathing space exercise (see Table 2).

After ordaining as a bhikșu ${ }^{44}$ in 2000 in Anhui Province, Jiewen graduated from the Jiezhuang Buddhist Studies Research Institute (Jiezhuang Foxue Yanjiusuo 戒幢佛學研究 所 $)^{45}$ in Suzhou in 2008. Apart from receiving training in psychology, Jiewen has also attended many retreats at various meditation centers in Myanmar, learning meditation practices from prominent teachers in Theravāda tradition. As the current vice president of the institute affiliated to Xiyuan Monastery (Xiyuansi 西園寺), Jiewen researches and teaches mindfulness meditation, Buddhist psychology, and Buddhist counselling services, such as the Avalokiteśvara hotline (guanyin rexian 觀音熱線) run by the institute. ${ }^{46}$

On the morning of Day 1, it was a one-hour session for the participants to participate in the raisin exercise, which is usually done in the first lesson of MBSR and MBCT. Nonetheless, Jiewen did give the guidance in a different way from the secular mindfulness programs. Jiewen firstly invited participants to sit in a comfortable and relaxing posture. After the Dhamma workers giving three pieces of raisin to each participant, he named this exercise as "beginner's mind of a meditation practitioner". He explained with his gentle and soft voice,

43 There are 47,700,000 search results of the Chinese term mindfulness (zhengnian 正念) on baidu.com https:/ / www.baidu.com/s?ie=utf- $8 \& \mathrm{f}=8 \& \mathrm{krsv}$ bp=1\&rsv_idx=1\&tn=baidu\&wd=\%E6\%AD \%A3\%E5\%BF\%B5\&fenlei=256\&oq=\%25E6\%25AD \%25A3\%25E5\%25BF\%25B5\%25E7\%25A6\%25AA \% 25E4\%25BF\%25AE\&rsv_pq=ebf9d519001d8bfc\&rsv_t=bf70ecbFdTuwSc\%2BRS91GDuELD\%2BlJWy3K1m9Mr\%2BE\%2FuJ\%2BEqoiO7cg8vo0 PS9s\&rqlang=cn\&rsv_dl=tb\&rsv_enter=0\&rsv_btype=t\&rsv_sug3=22\&rsv_sug1=17\&rsv_sug7=100\&inputT=3312\&rsv_sug4=4101\&rsv_sug=1 (accessed on 7 Februry 2021).

44 A title of ordained Buddhist monk with all precepts in Mahāyāna Buddhist tradition.

45 Jiezhuang Buddhist studies Institute is a renowned institute in China.

46 The background information of Jiewen is found on the online registration form of the "Healing depression Vipassanā Meditation Retreat in Winter Solstice 2019". Available online: https:/ /jinshuju.net/f/G2KzuH?from=singlemessage (accessed on 5 February 2021). 
What does a "beginner's mind" mean? It is a mind without any assumptions. Sometimes adults' world is full of concepts and experiences. But to children, the mind is full of curiosity. Hence, the mind of adults' mind is different from that of children. When a child visits a park, he finds everything meaningful. When he sees a small grass, an animal, a piece of stone, he is surprised. Take them in the hands, try to smell it and taste it. However, adults are not interested in them anymore... We live in a world filled with concepts and judgement. A meditator tries to let go the judgement and see the reality.

Jiewen further shared his experience of visiting the same mountain Taiping (Taipingshan 太平山) many times when he was a student. When he and his classmates felt bored about that, his teacher reminded them: "Every visit is the first visit. The weather has changed; people have changed; the landscape has changed. Our minds have changed." Then, Jiewen invited participants taking the perspective of "beginner's mind" to see, smell, touch, and taste the three pieces of raisins one by one carefully and mindfully. After that, participants were invited to share their experiences in the body and mind observed over the exercise. Jiewen listened mindfully and gave gentle responses one by one in a group-based counselling atmosphere.

On Day 2 evening, at the meditation hall, Jiewen gave a one-hour Dhamma talk about dealing with thinking, thoughts, and emotions, which can impact our well-being and quality of life. He explained that thoughts arise in the form of images, sounds, or concepts during sitting meditation or walking meditation. These thoughts continuously arise, decline, and change. People think all the time in their daily life. "Those who are depressed and anxious have a lot of experience. The brain thinks continuously without pause. It can't be stopped. Then depressive emotions would be explosive... Thinking is not always meaningful and beneficial ... Some philosophers in the West had thought too much and then collapsed." Jiewen then introduced that in Buddhism, there is a "right view" and "wrong view". Right view, which reflects the truth, can lead to a sense of liberation. Wrong view, with illusions about reality, can increase defilements rendering suffering. "Right view" (or "right understanding") (Samma-ditthi), is part of the noble eightfold path of the fourth noble truth, leading to the cessation of suffering. ${ }^{47}$ As Jiewen interpreted, there are three kinds of right view. The first one is the understanding of renunciation, which leads to liberation. The second right view is that without hatred, which causes anger and suffering. The third one is an attitude of non-harm. It includes not harming oneself and others. With right views in thinking, wrong views that render mental suffering, such as anxiety and depression, can be avoided.

Next, Jiewen introduced practical ways of dealing with thoughts and emotions during meditation. He categorized three types of thoughts. The first type refers to those meaningless passing thoughts, which arise when one is practicing sitting or walking meditation. Jiewen instructed, "They just come and go. You just ignore them. You even don't need to label them. They would arise and decline by themselves." The second type belongs to those meaningful thoughts, such as future plans. "For this type, you can make a mental note on them as 'planning, planning' or 'memory, memory"'. Then allow these thoughts to pass away. And then go back to your object of meditation, for example, observe the breath." Jiewen may borrow this technique of making a mental note of the mind-body state in developing insight from the vipassanā teaching of Mahāsi Sayadaw ([1944] 1999). As Mahāsi instructed, in sitting practice, during the rising of the abdomen, the meditator can make a mental note of "rising". During falling, the mind notes "falling". When the mind wanders, a meditator notes mentally "wandering, wandering" and then returns to noting the abdomen. If there are any body sensations, such as itching or numbness, meditator can just note the sensations and return to the breath at the abdomen.

47 The Noble Eightfold Path includes right view, right intention, right speech, right action, right livelihood, right effort, right mindfulness, and right concentration (see Gethin 1998, pp. 59-60). 
The third type of thoughts come along with emotions. Jiewen explained in detail, "It is because we attach to some strong emotions, like hatred and anxiety, which come with a lot of thoughts. They ruminate again and again forcefully out of control ... with lots of passing thoughts about how I was bullied and got hurt ... " For dealing with this type of thought, bringing mindfulness to the emotions is an effective way. "Ask myself what the emotions are behind those thoughts. Is it a sense of being wronged? Being hurt, wronged, and then hatred. Then we can move to observe these emotions one by one. Your tears would drop, wouldn't they?" Following that a sense of sadness, self-pity. and loneliness appears. Jiewen added with a therapeutic tone, "Now observe the sense of loneliness. Embrace yourself. A feeling of warmth and healing would arise. Then you can take a deep breath. The mind would be calm finally." Jiewen concluded that after the process of releasing those emotions behind, such as anger and sadness, calmness and forgiveness would arise.

I did have an individual interview with Jiewen about the use of some mindfulness exercises on Day 4 afternoon. As Jiewen commented, the eight-week mindfulness program is not aimed at walking the path of full liberation. ${ }^{48}$ Some practices and skills from the program are taken as a reference to him. He pointed out that indeed, many mindfulness practices, such as body scan, are originated from Buddhism. He used the 3-min breathing space framework to introduce insight meditation. Yet, one can also observe the body sensation and feelings without that framework. Jiewen added, "What I am more interested is the philosophical perspective behind it, for example, the concept of 'doing mode and being mode', 'acceptance', and 'non-judgement'. You know there is a unique philosophical perspective behind each therapy, such as Jungian therapy." "Doing mode and being mode", "acceptance", and "non-judgement" are commonly used concepts and psychological languages in the MBCT program (see Segal et al. 2012). Participants can easily identify whether they have accepted the emotions, or whether they perceive their anger in a non-judgemental way. With his great interest and experience in psychology and psychotherapy, Jiewen has explored a skillful way of applying psychological approaches and skills in Buddhist meditation teaching.

\section{Hybrid Training with Psychoanalytic and Physical Exercises}

Unlike many other vipassanā meditation retreats in contemporary China, several mindfulness exercises from secular mindfulness programs were included. More surprisingly, on Day 4 and 5 in this retreat, Jiewen guided participants to practice some psychoanalytic exercises, such as the inner child and symbol, which are related to self-exploration of some past subconscious traumatic events and emotions. During the Maoist period, psychology was labeled as "bourgeois pseudoscience" and abolished during the Cultural Revolution. However, since the turn of the century, training in counselling or psychotherapy has become a growing industry as a "psycho-boom" (xinli re 心理熱), in which the emerging middle class also has become the target (Huang 2014). One reason behind this trend was due to the mental health crises that emerged after the rapid socio-economic change. Another possible cause may be the massive over-generational trauma caused by political events and violence over the Cultural Revolution in the 1960s and 1970s (Lee 2011). With the supporting policy of the party-state, organizing "unified national exams" of psychoanalytic counsellors' training and certification, professional training, and business of psychotherapy have flourished in private agencies and public institutions, including hospitals and schools in major cities in China. As Sonya Pritzker (2016) has found in her recent ethnographic study, in the past decade, various kinds of spiritual practices and psychologically oriented "training classes" (peixunban 培訓班), including salons and

48 The final goal of the path of liberation is nibbana, cessation of all suffering. 
workshops on "the Inner Child" (neizai xiaohai 内在小孩) ${ }^{49}$ and "Family Constellation Therapy" (jiatingxitong pailie 家庭系統排列), have attracted many young urban Chinese in big cities, such as Beijing (Pritzker and Duncan 2019). Inner child therapy, which is a series of practices based in both Freudian and Jungian psychoanalysis, has developed by John Bradshaw (1992) over the last five decades in the West (Ivy 1993). Through the process of "regression" and "reparenting", the healing approach requires looking down at the infant with love as a wise and gentle adult. The inner child therapy has been used in Buddhist meditation teaching of Thich Nhat Hanh, the world-renowned Vietnamese Zen Master. ${ }^{50}$ His book "Reconciliation: Healing the Inner Child" (Thích 2010) was published in Chinese in Taiwan (Thích 2012) and mainland China (Thích 2014), respectively. It may explain that the inner child practice is well accepted in the Buddhist community in China.

In the session of practicing symbol exercise on Day 4, Jiewen firstly gave responses to some participants' questions about observing anxiety in daily life. Jiewen reminded participants that mindfulness practice is about exploring and understanding something behind our feelings and emotions. It is not about pushing them away. "Once you can feel difficulty in the body, try to observe this emotion and the breath. Be with them. Then they (body sensation and emotions) will start to change." Jiewen explained with the experience from a participant on the previous day. "In the 3-min breathing space exercise, during the step of expanding mindfulness to the whole body, a participant saw a sad image about her childhood. Her tears immediately rolled down. It is obviously caused by some suffering experience during her childhood. Now she discovered those feelings of being wronged behind that trauma."

As explained by Shusterman (2012, pp. 99-100), traumatic memory withdraws from consciousness by working implicitly through the body to preserve and reinforce its painful effect. Implicit traumatic memories can manifest as somatic complaints, such as flashbacks and other physical symptoms, such as sweating, racing heartbeat, frightening dreams, body tensing, and emotional numbness. Therapy facilitates making the implicit memory more explicit so that it can be treated. When some traumatic images about the past or childhood appear in the mind, Jiewen suggested the participants face them by understanding them and being with them gently. "At this moment, take care of this child and be with her as an adult. This process is powerful (in dealing with the past trauma)." Jiewen pointed out that although image and symbol may be an older expression compared with languages and words, some people may find difficulty observing them. Jiewen then guided participants to practice a symbol exercise by imagining a relative or a friend with a type of plant. Then a few participants enthusiastically shared their observed symbols, such as cactus, red rose, and sunflower, and related thoughts and feelings behind those symbols. Jiewen listened and gave responses one by one in the therapeutic approach.

On the following morning, at the meditation hall, Jiewen formally introduced the inner child exercise to the participants in an experienced way. He firstly invited us to close our eyes, sitting on our meditation mats, and allow an image of a child arising in the mind. "That child is yourself. It is the shadow side of you." He further explained with his gentle voice that everyone has both light and shadow, "At this moment, try to arise an image that you are not willing to accept or look at. The worst photo ... How old is this child? What is the child getting dressed? Facial expression and body posture? Maybe the child has fear, or sadness, anger or trauma now? Is this an abandoned child?" Jiewen then invited participants using loving-kindness to look at the child again.

We can now walk closely toward the child. If she is fine, we can hug her gently, embracing all sadness. If she is not fine, respect her feeling and quietly be with

49 There are 1,460,000 search results of the Chinese term inner child (neizai xiaohai 内在小孩) on baidu.com https: / /www.baidu.com/s?ie=utf-8\&f=8\& rsv_bp $=1 \&$ rsv_idx $=1 \& \mathrm{tn}=$ baidu\&wd=\%E5\%85\%A7\%E5\%9C\%A8\%E5\%B0\%8F\%E5\%AD \%A9\&fenlei=256\&rsv_pq=ea0996a6003286bd\&rsv_t $=81$ 564AEQwWGR0SlcGZGyyhPk4So9UCn0VeMIS\%2BBBde7NsEXDe6wGHCdsH3A\&rqlang=cn\&rsv_dl=tb\&rsv_enter=0\&rsv_n=2\&rsv_sug3=1 \&rsv_sug1=1\&rsv_sug7=100\&rsv_btype=i\&prefixsug=\%25E5\%2585\%25A7\%25E5\%259C\%25A8\%25E5\%25B0\%258F\%25E5\%25AD $\% 25 \mathrm{~A} 9 \&$ rsp $=$ 0\&inputT $=1598 \&$ rsv_sug4=1598 (accessed on 7 February 2021).

50 The inner child short meditation by Thich Nhat Hanh, https://www.youtube.com/watch?v=zauJYihF2fQ (accessed on 12 March 2021). 
her. Feel all the sadness, suffering, and trauma ... we can invite her to share with us in words. We can tell her that we care for her. Encourage her. Love her. Offer the child a gift.

Afterwards, participants were invited to feel the happiness of the child and give blessing to her. Then participants could take a deep breath and open their eyes before sharing about their experiences in this inner child exercise. In both the session of practicing symbol and the inner child exercises, Jiewen discussed the mind and mental suffering with a lot of psychological and psychoanalytic terms, such as light and shadow, defense mechanism, pride, self-esteem, inferiority, etc. By using a client-centered approach in his teaching, participants could freely share their difficult experiences, thoughts, emotions, and even tears. After the sharing of each participant, Jiewen often offered encouraging words in a gentle way. Participants could also have further enquiry in the small group interviews and requested private individual interviews. The meditation hall has been transformed into a group-therapy room. From my fieldwork, this teaching elements and approach can hardly be found in mainstream vipassanā meditation or traditional Chan meditation retreats, which adopt mainly a teacher-centered approach with "shock tactics", like shouting, kicking, and punching. ${ }^{51}$ Targeting people with depression may be a key consideration of including these psychoanalytic elements and approaches in this Buddhist meditation retreat.

Besides vipassanā meditation, mindfulness practices, and psychoanalytic exercises, there were also physical exercises and living Chan practices included as mind-body training in the daily schedule. On every early morning between 5:50 and 6:20, at the meditation hall, led by Wuyou, all participants practiced together the "swing hand exercise" (pingshuaigong 平甩功) ${ }^{52}$ for about 20 min following an audio instruction. ${ }^{53}$ The swing hand exercise, promoted by Taiwanese Meimen qigong Master Lee Feng-San 李鳳山, has been popularly practiced in Taiwan in the recent decade. ${ }^{54}$ There are claimed benefits of the swing hand exercise towards health cultivation and curing chronic diseases. Some recent scientific studies show positive effects of some qigong exercises, such as yijinjing 易筋經, on pain and depression (Liang et al. 2013). With the recent culture of health cultivation, the Swing hand exercise has been spread to mainland China. ${ }^{55}$ It is quite common that Chinese Buddhist monastics promote mind-body health cultivation exercises to their disciples and lay people. Yet, it is rare that they are included in a vipassanā meditation retreat, which is expected in the Theravāda tradition. Mindful yoga is commonly included in vipassanā meditation retreat. In this retreat, it was scheduled that all participants practiced mindful yoga together at the meditation hall every evening 6.00 to 6.30. However, there was no yoga instructor demonstrating various yoga postures in this session. Everyone followed the instruction of an audio recording of mindful yoga practices with standing postures selected only from the MBSR program. As I recognized, the voice of the audio recording belongs to Chen Te-Chung 陳德中, a Taiwanese pioneer MBSR teacher who has visited China teaching MBSR many times. ${ }^{56}$ Chen has also been actively involved in inviting Jon

51 From the "discourse records" of meetings between Chan masters and disciples, there is none of fixed guidance approaching towards awakening. Chan encounter dialogues recorded are like an art with spontaneous insight and creativity. Mazu (709-788) is the first Chan master using the controversial "shock tactics" techniques, such as shouing, hitting, and "illogical conversations" in teaching his students. Yet, the "shock tactics" have become a standard part of the Chan master's strategic repertoire (Hershock 2005, pp. 109-19).

52 This 10-minute Chinese version of the swing hand exercise is used in this retreat: https://www.youtube.com/watch? $=2 \mathrm{fGQ0W-RKfI \& list=}$ RDCMUCY1x0vK63MTXGbuhWNwOr3g\&index=2. (accessed on 5 February 2021).

53 On the first day, a 30-min version was used for practice. Some participants reflected that it was too long. Wuyou used a 10-min version for practicing 20 min on the second day.

54 Master Lee Feng-San has learnt qigong and taichi exercises from his family. He set up a charitable organization in 1989 promoting the swing hand exercise to children, adults, and the elderly in Asia and other parts of the word. See the official website of Meiman. Available online: https: / / www.meimen.org/ (accessed on 6 February 2021).

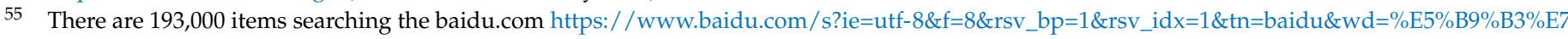
$\% 94 \%$ A9\%E5\%8A\%9F\&fenlei=256\&oq=\%25E5\%2585\%25A7\%25E8\%25A7\%2580\&rsv_pq=ebf9d519001daa45\&rsv_t=c3ceM\%2FvmWDTBddfy0 8c\%2Fs\%2FHVy9s0zSNwz\%2BewlsJG\%2BgY2BdPH3B4bKEqjNLA\&rqlang=cn\&rsv_dl=tb\&rsv_enter=0\&rsv_btype=t\&inputT=2896\&rsv_sug3 =35\&rsv_sug1=30\&rsv_sug7=101\&rsv_n=2\&rsv_sug2=0\&rsv_sug4=12585318 (accessed on 7 February 2021).

56 Wuyou confirmed that he used the audio recording of Chen when I enquired him in a group interview. 
Kabat-Zinn to give professional training in China (Lau 2021, pp. 191-92). As I guess, it may be not solemn to lie down in the meditation hall. Hence, all other sitting or lying down yoga postures of MBSR programs were not introduced in this retreat.

No matter whether it is in Chan or vipassana tradition or mindfulness programs, having meals as mindful eating is seen as one of the daily practices or living Chan (shenghuochan 生活禪). From early Buddhist texts, mindful eating not only can avoid over-eating, but also can establish mindfulness in the present moment (Anālayo 2020a). Following the hybridity of mind-body practices with vipassanā, mindfulness, and psychoanalytic exercises, in this retreat, the daily main ritual meals were also practiced in a hybrid way. The two ritual meals (guotang 過堂) were taken silently at the traditional Chan style dining hall; all participants, who were assigned seats according to the order of registration, had to line up outside the dining hall on time before entering that. While monks and males were seated on one side, females were assigned to sit on another side.

Nevertheless, unlike the general guotang practice in Chan monastery, nobody was responsible for spreading the same amount of food into the bowl of each person. In this retreat, everyone including monastics took their own food one by one in an individualized buffet style. This practice is similar to many other meditation centers in Myanmar and Thailand and vipassanā retreats in China. Before taking food, all were invited to chant a contemplation of food taking. Instead of chanting the standard liturgy of "five contemplations" in ancient Chinese language, participants chanted a contemplation of food in modern Chinese language. For example, "taking food is not for fun, not for pride, not for decoration. It is for maintaining the body for survival and spiritual practice ... " It reminded participants of taking enough but not a too large amount of food for practice. Finally, loving-kindness spread with the donors is practiced. "May the donors of four requisites (parishkara) (clothes, food, accommodation, and medicine) have no hatred, mental suffering, and physical suffering. May they maintain the wellbeing. May all beings be healthy and happy. Sadhu sadhu sadhu!"

As all lay participants observed the Nine Uposatha precepts and recited them in both Pāli and Chinese every early morning, theoretically, participants were expected to observe not eating after noon, according to vipassanā meditation retreats held in China and meditation centers in Myanmar in general. ${ }^{57}$ Nonetheless, in this retreat, there was a session in the evening in which participants could have some brown sugar water. Some packets of instant oatmeal, biscuits, and peanuts were also prepared at the dining hall for those who may need it. As explained by Wuyou, this was a flexible arrangement for those who were novice meditators, especially some non-Buddhists with depression. Yet, experienced meditators could observe the precepts in a stricter way compared with novices by fasting after noon. Overall, the main meals arrangement in this retreat was more individual-oriented compared with that of traditional guotang practice at traditional Chan monasteries. More importantly, although participants had their meals in the traditional Chan style dining hall with the name guotang, the style of eating practice was not solely Chan's, but was in a hybrid way.

In this retreat, besides attending learning sessions and practicing mindful sitting at the meditation hall, participants were assigned to work on mindful chores for about half an hour, for example, sweeping, cleaning cooking utensils, or cleaning the public toilets. Working on chores is seen as a meditation practice observing the mind and body. Furthermore, participants could spend about four hours on mindful walking practice every day in the Chinese Buddhist style courtyard of the monastery or villages nearby (Figure 3). In vipassanā meditation or secular mindfulness programs, mindful walking practice take a prominent role in establishing awareness of the present mind-body experience. It is recommended by many vipassanā meditation teachers, such as Mahāsi Sayadaw ([1944] 1999), to expel drowsiness or torpor with walking meditation. Mindful walking may be effective to

57 From my fieldwork in the last decade, at a vipassanā meditation retreat in Goenka's tradition, a novice can have a piece of fruit (e.g., an apple) after noon, while experienced meditators can have lemon water only. At meditation centers in Myanmar, no solid food is allowed in general. However, drinking after noon is varied depending on the traditions. At some centers, chocolate, coffee, tea, or milk product are not allowed. 
maintain mindfulness practice and further improve psychological functioning for reducing negativeAvailable online: (accessed on 15 March 2012) emotions (Gotink et al. 2016).

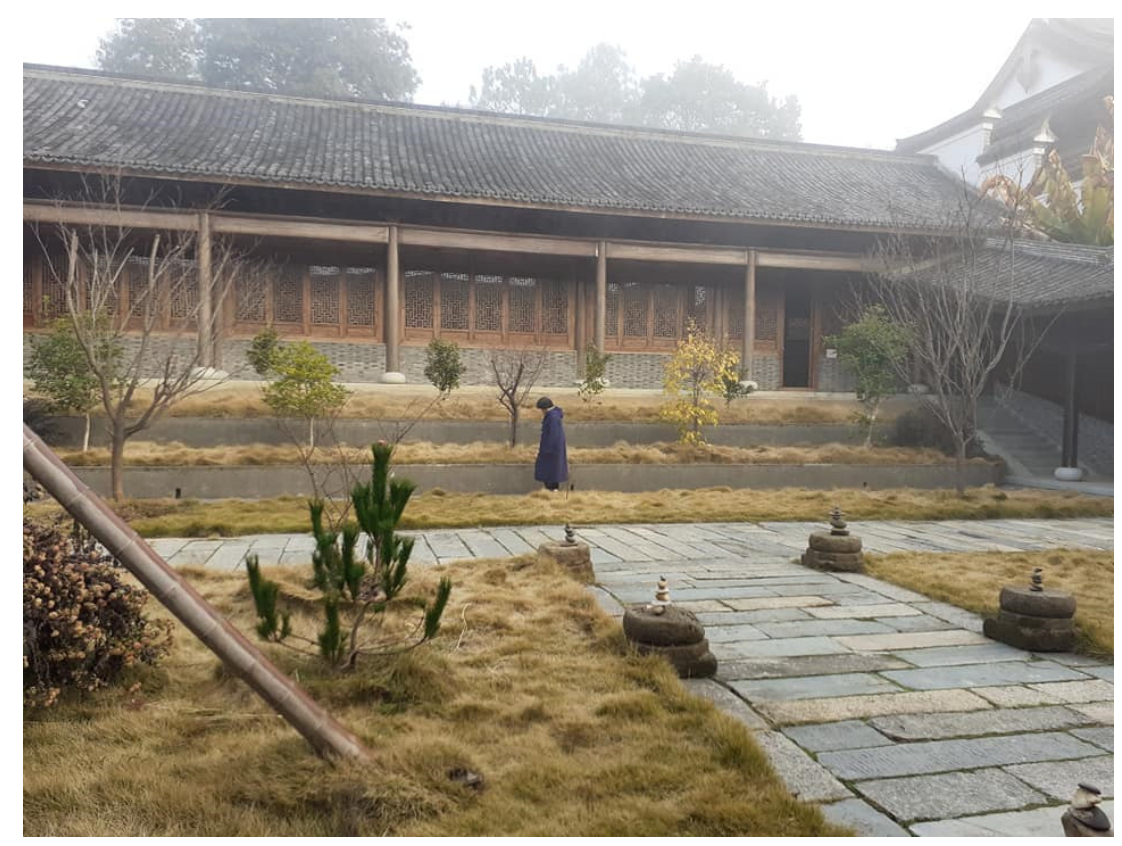

Figure 3. Walking meditation.

\section{Conclusion: "Re-Religioning" of Meditation in Chinese Buddhism?}

As one of the global and historical religions, Buddhism provides many examples of building a transnational network developed by missionary activities of pilgrimage and travelling. They include the modern Buddhist international organizations, such as the Maha Bodhi Society in the late 19th century and World Fellowship of Buddhists in the 20th century (Schedneck 2017), and recent lay meditation networks in Chinese societies (Lau 2021). In this paper, from a recent case of an eight-day vipassanā (neiguan) meditation retreat targeting Han Chinese with depression at a Chan monastery in contemporary China, an example of the intersection of modernization, globalization, transnationalism, syncretism, and self-reflexivity in teaching Buddhist meditation today in Chinese society is demonstrated. By examining the retreat schedule and teaching content of the two experienced prominent Chinese Buddhist monastic teachers, participants learnt to contemplate the body as a key object for transforming physical illness and mental suffering with a series of syncretic mind-body activities with self-reflexivity: vipassanā meditation Theravāda tradition, practices from secular mindfulness programs, observing the Nine Uposatha precepts as the ethical foundation and reciting them in Pāli and Chinese, inner child therapy, guotang, and daily chores. Due to the socio-political restriction and state regulations about religion, neither establishing a Theravāda monastery nor holding vipassanā retreat at a secular venue could be possible in the mainland. Hence, the hybrid mode of teaching meditation in Theravāda and Mahāyāna traditions at Chinese monasteries has been common in contemporary China since the transnational meditation introduced around the turn of the century (see Lau 2017). Nevertheless, the inclusion of mindfulness and psychoanalytic exercises targeting non-Buddhists with therapeutic effects may add value to the social role of Buddhism in responding social crises.

In spite of the traditional Chinese Chan architecture style (Figure 4) throughout this monastery, in contrast, in this meditation retreat, there is a lack of traditional way of Chan school teaching with "sticks and shouting" (bang he 棒喝). Participants who were falling asleep would never be hit with the "fragrant sword" by any Buddhist monks. Instead of the "shock tactics" from Chan school, Wuyou and Jiewen shared the teachings and gave Dhamma talks with a gentle and soft voice. Teacher-student interaction was frequently 
intertwined in the retreat. Participants could freely ask questions clarifying their doubts of practice, share their experiences, and even express their emotions and tears publicly after each teaching session. Both monastic teachers gave responses clearly with positive acknowledgement to each of them one by one. A client-centered counselling approach was explicitly practiced in group interviews and individual interviews to allow the participants to speak out about their own experiences and challenges of practices. In the late modern context, Kim Knott (2016, p. 41) argues that more people choose to "turn to the self" and individualize their religious experiences. As explained by McMahan (2008), Taylor used the term "massive subjective turn" to refer to a "new kind of selfhood, constituted by increased self-reflexivity" with the rise of Romantic, psychological, and rationalist influence since the nineteenth century (p. 188). One's own experience has become an explicit object of reflection and self-awareness. McMahan uses the term "subjective turn" to examine the trend of detraditionalization and privatization of Buddhist meditation after the encounter with Western modernity (pp. 183-92).

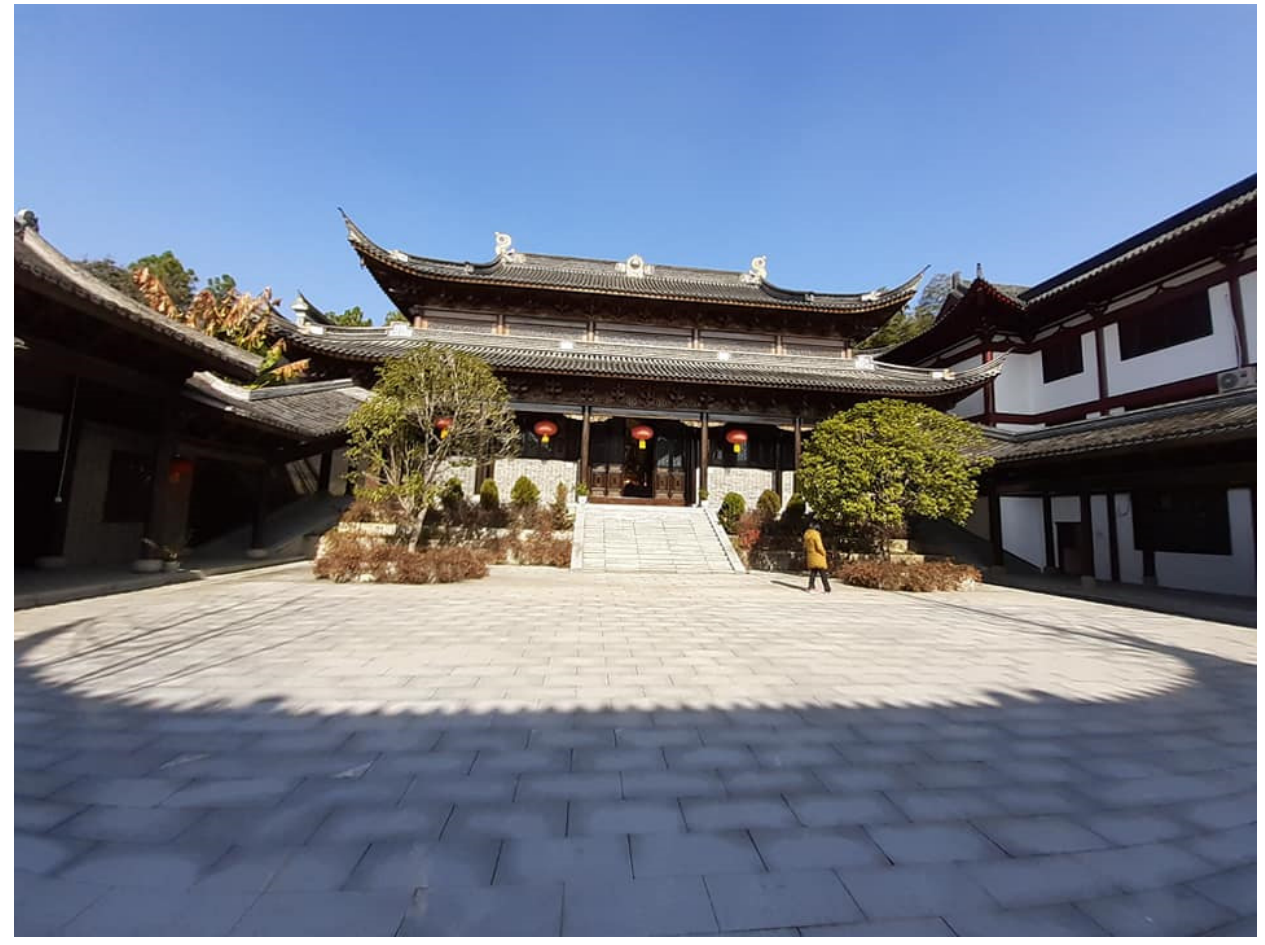

Figure 4. Architecture style.

With the recent trend of privatization of health cultivation and mind-body healing in China (Chen 2001), I argue that the hybrid mode of privatization of meditation and therapeutic somatic style, for example, the warm and gentle approach and voice, applied by the two educated meditation teachers is a response to the emerging need of healing of urban educated people via self-reflexivity (Lau 2017). Previous research showed that Chinese meditators who traveled to Southeast Asia enjoy having individual room for practicing meditation and individual interviews with meditation teachers in Myanmar (Lau 2020a, p. 117), which cannot easily happen in most traditional Chinese Buddhist monasteries.

In the mindfulness movement in the United States, as Jeff Wilson (2014) points out, Buddhist practice has been removed from the realm of religion and medicalized as the property of psychologists, doctors, scientists, and counselors. With the influence of secularization in the West, meditation can be taught easily by non-Buddhists. Clients of mindfulness programs are not expected to become a Buddhist by taking refuge or reading scriptures, and Buddhists have no special claim to mindfulness practice. A similar 
phenomenon is found in Asia after mindfulness programs have been spread in Chinese societies, such as Hong Kong, Taiwan, and China today (Lau 2021). However, this case study in China may share a very different perspective of the medicalization of Buddhist meditation in the West. Unlike usual vipassanā meditation retreats held in contemporary China, surprisingly, mindfulness exercises from those evidenced-based secular programs, and some psychoanalytic exercises, such as the inner child and symbol, were included to explore any subconscious traumatic events and emotions. The skillful guidance of applying psychological approaches and skills in Buddhist meditation could facilitate participants, especially those with traumatic experience or depression, to deal with the manifested strong emotions as a self-healing process after starting mindfulness practices on the body. Metcalf (2002, pp. 348-64) points out that apart from the endeavor of Orientalists and Western enthusiasts, some Asian Buddhist teachers have also contributed to the modernized image of Buddhism over the last century. Western psychologists and scientists have secularized Buddhist meditation since the 1980s; however, in this case, practices of psychologized mindfulness and psychoanalysis were taken to facilitate Buddhist meditation for alleviating mental and physical suffering. The intertwining of religious and secular motivations over the retreat training has blurred the strict boundary of the religious and the secular. As suggested by McMahan (2020, p. 54), with the decline of the traditional religious prestige, Buddhist communities in contemporary China have interacted more with secular institutions and cultural forces to gain greater legitimacy and prestige. McMahan uses the term "de-religioning of meditation" (McMahan 2020, p. 47) in the discussion of Goenka and his movement of promoting vipassanā to the world in a secular, scientific and decontextualized approach. Here, I try to argue that the inclusion of mindfulness exercises from secular programs and psychoanalytic exercises in a Buddhist meditation retreat may be an attempt of re-contextualizing and "re-religioning meditation" in Chinese Buddhism.

Due to the restriction of the state religious regulations, hybridity of embodied Buddhist practices is not rare from the recent studies of Buddhist revival in China. For example, hybrid practices of mahasati dynamic vipassanā from Thai tradition with Chinese Mahāyāna, Chan school, and Tibetan rituals, and mixed style of architecture and iconography are found in Shifosi 石佛寺 in Sichuan 四川 (Bianchi n.d.; Lau 2020b) to fit the needs of devotees. In this study, I argue that the hybrid mode of embodied practices vipassanā and mindfulness and psychoanalytic exercises could allow non-Buddhist meditators to learn to overcome depression and other afflictions in an easier way, compared with traditional Chan school chanqi retreat or intensive style vipassanā meditation retreat.

In conclusion, by investigating a recent vipassanā meditation retreat organized for people with depression at a Han Chinese Buddhist monastery, I argue that it may be an active response from the Chinese Buddhist communities towards the recent yearning of individualized self-healing bodily practices and the social trend of the "subjective turn" and self-reflexivity in contemporary Chinese society. The hybrid inclusion of mindfulness exercises from secular programs and psychoanalytic exercises into a vipassanā meditation retreat may reflect an attempt of re-contextualizing and re-religioning meditation in Chinese Buddhism, a constant changing notion.

Funding: This research received no external funding.

Institutional Review Board Statement: Not applicable.

Informed Consent Statement: Informed consent was obtained from all subjects involved in the study.

Data Availability Statement: Not applicable.

Conflicts of Interest: The author declares no conflict of interest. 


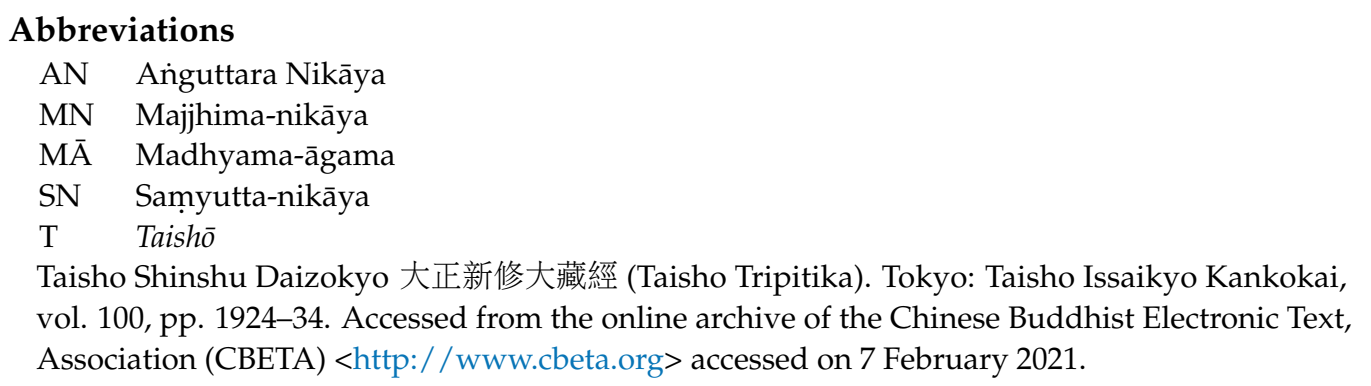

\section{References}

Anālayo, Bhikkhu. 2015. Healing in early Buddhism. Buddhist Studies Review 32: 19-33. [CrossRef]

Anālayo, Bhikkhu. 2016. Early Buddhist Mindfulness and Memory, the Body, and Pain. Mindfulness 7: 1271-80. [CrossRef]

Anālayo, Bhikkhu. 2020a. The Myth of McMindfulness. Mindfulness 11: 472-79. [CrossRef]

Anālayo, Bhikkhu. 2020b. Somatics of Early Buddhist Mindfulness and How to Face Anxiety. Mindfulness 11: 1-1526. [CrossRef] [PubMed]

Ashiwa, Yoshiko, and David L. Wank. 2005. The globalization of Chinese Buddhism: Clergy and devotee networks in the Twentieth century. International Journal of Asian Studies 2: 217-19. [CrossRef]

Bianchi, Ester. 2017. Yi Jie Wei Shi 以戒為師: Theory and Practice of Monastic Discipline in Modern and Contemporary Chinese Buddhism. Studies in Chinese Religions 3: 111-41. [CrossRef]

Bianchi, Ester. n.d. Theravāda Meditation in Modern and Contemporary Chinese Buddhism with a Focus on Mahasati Dynamic Vipassanā in Shifosi 石佛寺, Sichuan. In Metamorphosis of Buddhism in New Era China. Edited by Ioshiko Ashiwa, David Wonk and Ji Zhe. Unpublished Manuscript.

Bradshaw, John. 1992. Homecoming: Reclaiming and Championing Your Inner Child. New York: Bantam Books.

Braun, Erik. 2013. The Birth of Insight: Meditation, Modern Buddhism, and the Burmese Monk Ledi Sayadaw. Chicago and London: The University of Chicago Press.

Chan, Cecilia, Ying Ho, Petula Sik, and Esther Chow. 2002. A Body-Mind-Spirit Model in Health. Social Work in Health Care 34: 261-82. [CrossRef] [PubMed]

Chen, Nancy N. 2001. Health, wealth, and the good life. In China Urban: Ethnographies of Contemporary Culture. Edited by Nancy N. Chen, Constance D. Clark, Suzanne Z. Gottschang and Lyn Jeffery. Durham: Duke University Press, pp. 165-82.

Collins, Steven. 2000. The body in Theravāda Buddhist monasticism. In Religion and the Body. Cambridge Studies in Religious Traditions. Edited by Sarah Coakley. Cambridge: Cambridge University Press, pp. 185-204.

Connor, Linda H., and Geoffrey Samuel. 2000. Healing Powers and Modernity: Traditional Medicine, Shamanism, and Science in Asian Societies. Westport, CT: Bergin \& Garvey.

Cook, Joanna. 2010. Meditation in Modern Buddhism: Renunciation and Change in Thai Monastic Life. Cambridge: Cambridge University Press.

Dear, David. 2012. Chinese Yangsheng: Self-help and Self-image. Asian Medicine: Tradition and Modernity 7: 1-33. [CrossRef]

Dillion, Michael. 2009. Chapter 24 China rising and a 'harmonious society'? In Contemporary China-An Introduction. Abingdon: Routledge, pp. 253-59.

Doran, Natasha J. 2014. Experiencing Wellness within Illness: Exploring a Mindfulness-Based Approach to Chronic Back Pain. Qualitative Health Research 24: 749-60. [CrossRef] [PubMed]

Fan, Lizhu. 2003. Popular religion in contemporary China. Social Compass 50: 449-57.

Fisher, Gareth. 2011. Chapter 3 Morality books and the regrowth of lay Buddhism. In Religion in Contemporary China. Edited by Adam Chau. Abingdon: Routledge.

Gethin, Rupert. 1998. The Foundations of Buddhism. Oxford: Oxford University Press.

Goldberg, Kory. 2014. Chapter 3 For the Benefit of Many: S.N. Goenka's Vipassanā Meditation Movement in Canada. In Flowers on the Rock: Global and Local Buddhisms in Canada. Edited by John S. Harding, Victor Sogen Hori and Alexander Soucy. Montreal and Kingston: McGill-Queen's University Press, pp. 79-100.

Gotink, Rinske A., Karlijn S. F. M. Hermans, Nicole Geschwind, Reinier De Nooij, Wouter T. De Groot, and Anne E. M. Speckens. 2016. Mindfulness and mood stimulate each other in an upward spiral: A mindful walking intervention using experience sampling. Mindfulness 7: 1114-22. [CrossRef] [PubMed]

Gu, Jenny, Clara Strauss, Rod Bond, and Kate Cavanagh. 2015. How Do Mindfulness-based Cognitive Therapy and Mindfulness-based Stress Reduction Improve Mental Health and Wellbeing? A Systematic Review and Meta-analysis of Mediation Studies. Clinical Psychology Review 37: 1-12. [CrossRef]

Hart, William. 1987. The Art of Living: Vipassana Meditation as Taught by S. N. Goenka. Onalaska: Harper \& Row.

Hershock, Peter. 2005. Chan Buddhism: Dimensions of Asian Spirituality. Honolulu: University of Hawai'i Press.

Hershock, Peter. 2019. Chan Buddhism. In The Stanford Encyclopedia of Philosophy. Spring 2019 Edition. Available online: https: / / plato.stanford.edu/archives/spr2019/entries/buddhism-chan/ (accessed on 1 February 2021). 
Huang, Hsuan-Ying. 2014. Chapter 10 The emergence of the psycho-boom in contemporary urban China. In Psychiatry and Chinese History. Edited by Howard Chiang. London: Pickering \& Chatto, pp. 183-204.

Ivy, Marilyn. 1993. Have You Seen Me? Recovering the Inner Child in Late Twentieth-Century America. Social Text 37: 227-52. [CrossRef]

Ji, Zhe. 2011. Buddhism in the reform era: A secularized revival? In Religion in Contemporary China. Edited by Adam Yuet Chau. Abingdon: Routledge, pp. 32-52.

Jordt, Ingrid. 2007. Burma's Mass Lay Meditation Movement: Buddhism and the Cultural Construction of Power. Athens: Ohio University Press.

Kabat-Zinn, Jon. 2005. Full Catastrophe Living: Using the Wisdom of Your Body and Mind to Face Stress, Pain, and Illness. New York: Bantam Dell. First published 1990.

Kabat-Zinn, Jon, Ann O. Massion, J. Kristeller, Linda Gay Peterson, Kenneth E. Fletcher, Lori Pbert, William R. Lenderking, and Saki. F. Santorelli. 1992. Effectiveness of a meditation based stress reduction program in the treatment of anxiety disorders. The American Journal of Psychiatry 149: 936-43. [PubMed]

Kleinman, Arthur. 1986. Social Origins of Distress and Disease: Depression, Neurasthenia, and Pain in Modern China. New Haven: Yale University Press.

Kleinman, Arthur, Veena Das, and Margaret M. Lock, eds. 1997. Social Suffering. Berkeley: University of California Press.

Kleinman, Arthur, Yunxiang Yan, Jing Jun, Sing Lee, Everett Zhang, Pan Tianshu, Wu Fei, and Guo Jinhua. 2011. Chapter 1 Introduction. In Deep China: The Moral Life of the Person: What Anthropology and Psychiatry Tell Us about China Today. Edited by Arthur Kleinman, Yunxiang Yan, Jing Jun, Sing Lee, Everett Zhang, Pan Tianshu, Wu Fei and Guo Jinhua. Berkeley: University of California Press, pp. 1-35.

Knott, Kim. 2016. Religions in the Modern World: Traditions and Transformations, 3rd ed. Edited by Linda Woodhead, Hiroko Kawanami and Christopher H. Partridge. New York: Routledge, pp. 15-40.

Kolstad, Arnulf, and Nini Gjesvik. 2013. Perceptions of Minor Mental Health Problems in China. Mental Health, Religion E Culture 16: 335-51.

Kolstad, Arnulf, and Nini Gjesvik. 2014. Collectivism, Individualism, and Pragmatism in China: Implications for Perceptions of Mental Health. Transcultural Psychiatry 51: 264-85. [CrossRef] [PubMed]

Lau, Ngar-sze. 2017. Desire for self-healing: Lay practice of satipaț̣̂āna in contemporary China. Asian Medicine: Tradition and Modernity 12: 317-35. [CrossRef]

Lau, Ngar-sze. 2018. Modernising Buddhism: Emergence of Theravāda Meditation Communities in Contemporary China. Ph.D. dissertation, Lancaster University, Lancaster, UK, March.

Lau, Ngar-sze. 2020a. Recent Emergence of Theravāda Meditation Communities in Contemporary China. In Buddhism in the Global Eye: Beyond East and West. Edited by John Harding, Victor Sōgen Hori and Alec Soucy. London: Bloomsbury Academic, pp. 103-20.

Lau, Ngar-sze. 2020b. Hybrid form of Buddhist meditation practice in contemporary China: Discussing the case of Mahasati Dynamic meditation. International Journal for the Study of Chan Buddhism and Human Civilization 7: 64-79.

Lau, Ngar-sze. 2021. Pilgrimage, travelling gurus and transnational networks: Lay meditation movement in Contemporary Chinese societies. In Routledge International Handbook of Religion in Global Society. Edited by Jayeel Serrano Cornelio, Francois Gauthier, Tuomas Martikainen and Linda Woodhead. Abingdon: Routledge, pp. 187-98.

Lee, Sing. 2011. Chapter 5 Depression: Coming of age in China. In Deep China: The Moral Life of the Person: What Anthropology and Psychiatry Tell Us about China Today. Edited by Arthur Kleinman, Yunxiang Yan, Jing Jun, Sig Lee, Everett Zhang, Pan Tianshu, Wu Fei and Guo Jinhua. Berkeley: University of California Press, pp. 177-212.

Li, Jie, and Nikolas Rose. 2017. Urban Social Exclusion and Mental Health of China's Rural-urban Migrants-A Review and Call for Research. Health \& Place 48: 20-30. [CrossRef]

Liang, Dong, Jae-Bum Lee, Yong-Kuk Kim, and Young-Sook Kim. 2013. The Effects of Health Qigong Training of Elderly Single Women on Pain Consciousness and Depression. International Journal of Applied Sports Sciences: IJASS 25: 118-26. [CrossRef]

Liang, Di, Vickie M. Mays, and Wei-Chin Hwang. 2018. Integrated Mental Health Services in China: Challenges and Planning for the Future. Health Policy and Planning 33: 107-22. [CrossRef] [PubMed]

Mahāsi Sayadaw. 2009. Dhamma Therapy Revisited: Cases of Healing through Vipassanā Meditation. Translated by Aggacitta Bhikkhu. Taiping: Sāsanārakkha Buddhist Sanctuary. First published 1976.

Mahāsi Sayadaw. 1999. Practical Insight Meditation 實用内觀練習. Translated by Lin Chung-on 林崇安. Taoyuan: Insight Educational Foundation. First published 1944.

McMahan, David. 2008. The Making of Buddhist Modernism. Oxford: Oxford University Press.

McMahan, David. 2020. Buddhism and Global Secularisms. In Buddhism in the Global Eye: Beyond East and West. Edited by John Harding, Victor Sōgen Hori and Alec Soucy. London: Bloomsbury Academic, pp. 42-55.

Metcalf, Franz Aubrey. 2002. Chapter 22 The encounter of Buddhism and psychology. In Westward Dharma: Buddhism beyond Asia. Edited by Charles S. Prebish and Martin Baumann. Berkerley: California University Press, pp. 348-64.

Moussavi, Saba, Somnath Chatterji, Emese Verdes, Ajay Tandon, Vikram Patel, and Bedirhan Ustun. 2007. Depression, Chronic Diseases, and Decrements in Health: Results from the World Health Surveys. The Lancet 370: 851-58. [CrossRef]

Myers, Neely, Sara Lewis, and Mary Ann Dutton. 2015. Open Mind, Open Heart: An Anthropological Study of the Therapeutics of Meditation Practice in the US. Cult Med Psychiatry 39: 487-504. [CrossRef] [PubMed] 
Ng, Siu-man. 2003. Tiannian Gongxiang: Zhongyi Yangsheng Yu Shenxinling Jiankang 天年共享: 中醫養生與身心靈健康 [Longevity shared: Chinese Medicine Yangsheng and Body-Mind-Spirit Wellness]. Hong Kong: Veritas Book House.

Ng, Siu-man, Cecilia L. W. Chan, David Y. F. Ho, Yu-Yeuk Wong, and Rainbow T. H. Ho. 2006. Stagnation as a Distinct Clinical Syndrome: Comparing 'Yu' (Stagnation) in Traditional Chinese Medicine with Depression. The British Journal of Social Work 36: 467-84. [CrossRef]

Palmer, David. 2007. Qigong Fever. Body, science and Utopia in China. New York: Columbia University Press.

Perry, Elizabeth J., and Mark Selden. 2010. Chinese Society: Change, Conflict and Resistance, 3rd ed. London: Routledge.

Poceski, Mario. 2020. Mindfulness, Cultural Appropriation, and the Global Diffusion of Buddhist Contemplative Practices. International Journal for the Study of Chan Buddhism and Human Civilization 7: 1-15.

Pritzker, Sonya E. 2016. New age with Chinese characteristics? Translating inner child emotion pedagogies in contemporary China. Ethos 44: 150-70. [CrossRef]

Pritzker, Sonya E., and Whitney L. Duncan. 2019. Technologies of the Social: Family Constellation Therapy and the Remodeling of Relational Selfhood in China and Mexico. Culture, Medicine and Psychiatry 43: 468-95. [CrossRef] [PubMed]

Purser, Ronald E. 2019. McMindfulness: How Mindfulness Became the New Capitalist Spirituality. London: Repeater.

Ren, Xinwen, Shicheng Yu, Wenlan Dong, Peng Yin, Xiaohui Xu, and Maigeng Zhou. 2020. Burden of Depression in China, 1990-2017: Findings from the Global Burden of Disease Study 2017. Journal of Affective Disorders 268: 95-101. [CrossRef] [PubMed]

Roy, Alexandra, Susan Druker, Elizabeth A. Hoge, and Judson A. Brewer. 2020. Physician Anxiety and Burnout: Symptom Correlates and a Prospective Pilot Study of App-Delivered Mindfulness Training. JMIR MHealth and UHealth 8: E15608. [CrossRef]

Rycroft-Malone, Jo, Felix Gradinger, Heledd Owen Griffiths, Rob Anderson, Rebecca Susan Crane, Andy Gibson, Stewart W. Mercer, and Willem Kuyken. 2019. 'Mind the gaps': The accessibility and implementation of an effective depression relapse prevention programme in UK NHS services: Learning from mindfulness-based cognitive therapy through a mixed-methods study. BMJ Open 9: e026244. [CrossRef]

Salguero, C. Pierce. 2013. Fields of Merit, Harvests of Health: Some Notes on the Role of Medical Karma in the Popularization of Buddhism in Early Medieval China. Asian Philosophy 23: 341-49. [CrossRef]

Salguero, C. Pierce. 2015. Toward a Global History of Buddhism and Medicine. BSRV 32: 35-61. [CrossRef]

Schedneck, Brooke. 2017. Buddhist International Organizations. In The Oxford Handbook of Contemporary Buddhism. Edited by Michael Jerryson. Oxford: Oxford University Press.

Schlütter, Morten. 2008. Chapter 3 Procreation and Patronage in the Song Chan School. In How Zen Became Zen: The Dispute over Enlightenment and the Formation of Chan Buddhism in Song Dynasty China. Honolulu: University of Hawai'i Press, pp. 55-77.

Segal, Zindel V., Mark Williams, and John Teasdale. 2012. Mindfulness-based Cognitive Therapy for Depression, 2nd ed. New York: Guilford Press.

Shusterman, Richard. 2012. Thinking through the Body: Essays in Somaesthetics. Cambridge: Cambridge University Press.

Singer, Merrill, and Pamela I. Erickson. 2013. Global Health: An Anthropological Perspective. Long Grove: Waveland Press.

Steinmuller, Hans, and Fei Wu. 2011. School killings in China: Society or wilderness? Anthropology Today 27: 10-13.

Sun, Yan. 2004. Introduction. In Corruption and Market in Contemporary China. Ithaca: Cornell University Press, pp. 1-25.

Suzuki, Shunryu. 1995. Zen Mind, Beginner's Mind. New York: Weatherwill. First published 1970.

The Lancet. 2015. Mental Health in China: What Will Be Achieved by 2020? The Lancet 385: 2548. [CrossRef]

Thích, Nhât Hạnh. 2010. Reconciliation: Healing the Inner Child. Berkeley: Parallax Press.

Thích, Nhât Hạnh. 2012. 和好: 療癒你的内在小孩 [Reconciliation: Healing the Inner Child]. Translated by Wangqiao 汪橋. Taipei: Ziyouzhiqiu.

Thích, Nhât Hạnh. 2014. 和好: 疗愈你的内在小孩 [Reconciliation: Healing the Inner Child]. Translated by Wangqiao 汪桥. Taipei: Ziyouzhiqiu.

Wang, Xiaoyu, Junyi Li, Chengwei Wang, and Jianqin Lv. 2020. The Effects of Mindfulness-based Intervention on Quality of Life and Poststroke Depression in Patients with Spontaneous Intracerebral Hemorrhage in China. International Journal of Geriatric Psychiatry 35: 572-80. [CrossRef] [PubMed]

Williams, J., Mark G., and Jon Kabat-Zinn. 2013. Introduction. In Mindfulness: Diverse Perspectives on its Meaning, Origins and Applications. Edited by Mark G. Williams and Jon Kabat-Zinn. Abington: Routledge.

Wilson, Jeff. 2014. Chapter 3 Medicalizing mindfulness. In Mindful America: The Mutual Transformation of Buddhist Meditation and American Culture. Oxford: Oxford University Press, pp. 75-104.

World Health Organization. 2020. Available online: https://www.who.int/news-room/fact-sheets/detail/depression (accessed on 2 February 2021).

Wu, Fei. 2010. Suicide and Justice: A Chinese perspective. London and New York: Routledge.

Wu, Fei. 2011. Chapter six Suicide, a modern problem in China. In Deep China: The Moral Life of the Person: What Anthropology and Psychiatry Tell Us about China Today. Edited by Arthur Kleinman, Yunxiang Yan, Jing Jun, Sig Lee, Everett Zhang, Pan Tianshu, Wu Fei and Guo Jinhua. Berkeley: University of California Press, pp. 213-36.

Yao, Xinzhong, and Paul Badham. 2007. Chapter 5 Buddhism and the religious experience of urban residents. In Religious Experience in Contemporary China. Cardiff: University of Wales Press, pp. 96-116. 